УДК 550.361.2

DOI: https://doi.org/10.17308/geology.2021.3/3651

ISSN 1609-0691

Поступила в редакцию: 30.07.2021

Принята к публикации: 02.09.2021

Опубликована онлайн: 07.10.2021

\title{
Теплогенерация пород фундамента центральной части Восточно-Европейского кратона
}

\author{
(C) 2021 В. Н. Глазнев ${ }^{\bowtie 1,2}$, О. М. Муравина ${ }^{1}$, М. В. Минц ${ }^{3}$, Д. М. Чернышова \\ ${ }^{1}$ Воронежский государственный университет, \\ Университетская пл., 1, 394018, Воронеж, Российская Федерация \\ ${ }^{2}$ Геологический институт Кольского научного центра РАН, \\ ул. Ферсмана, 14, 184209, Апатиты, Российская Федерация \\ ${ }^{3}$ Геологический институт РАН, Пыюжевский пер., 7, стр. 1, \\ 119017, Москва, Российская Федерация
}

\begin{abstract}
Аннотация
Введение: Рассматриваются общие принципы создания комплексных геофизических моделей литосферы центральной части Восточно-Европейского кратона и роль геотермических моделей в таких построениях. С целью формирования достоверного начального приближения термической модели верхней коры выполнено обобщение данных о содержании теплогенерирующих элементов в породах раннедокембрийского фундамента.

Исходные данные: Рассмотрены особенности валового содержания редких и рассеянных элементов, полученные методом индуктивно-связанной плазменной масс-спектрометрии, в образцах типичных пород региона исследований. Составлена сводная база данных по содержанию теплогенерирующих элементов (калия, тория, урана) и валовому содержанию кремнезёма в типичных породах кристаллического фундамента платформы.

Оценка теплогенеращии пород фундамента: На основе исходных материалов о концентрации радиогенных элементов был выполнен расчёт теплогенерации пород кристаллического фундамента территории. Для оценки величин теплогенерации использовались сведения о плотности пород фундамента Восточно-Европейского кратона и его отдельных частей. Полученные результаты оценок теплогенерации характеризуют верхнюю неоднородную часть фундамента, распространяющуюся до нижней границы гравиактивного слоя региона.

Анализ данных и обсуждение: Для Воронежского кристаллического массива получена величина теплогенерация пород раннедокембрийского фундамента, варьирующая в диапазоне от 0.1 до 7.54

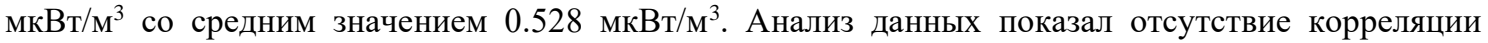
между плотностью пород фундамента региона и рассчитанными величинами их теплогенерации. Выявлена устойчивая связь содержания кремнезёма $\left(\mathrm{SiO}_{2}\right)$ с величиной рассчитанной теплогенерации пород. Для главных групп пород фундамента установлена тенденция связи теплогенерации с составом пород, и отсутствие связи с возрастом формирования пород.

Заключение: Сформулированы основные результаты проведённого исследования и намечены пути формирования начального приближения для теплогенерации верхнего слоя земной коры в термической модели литосферы региона.

Ключевые слова: Восточно-Европейский кратон, докембрийский фундамент, теплогенерация пород
\end{abstract}

Контент доступен под лицензией Creative Commons Attribution 4.0 License.

\footnotetext{
$\bowtie$ Глазнев Виктор Николаевич, e-mail: glaznev@geol.vsu.ru
} 
Источник финансирования: гранты РФФИ № 19-0500336 и № 20-05-00190

Для цитирования: Глазнев В. Н., Муравина О. М., Минц М. В., Чернышова Д. М. Теплогенерация пород фундамента центральной части Восточно-Европейского кратона // Вестник Воронежского государственного университета. Серия: Геология. 2021. №3. С. 6078. DOI: https://doi.org/10.17308/geology.2021.3/3651

\section{Введение}

Создания трёхмерных геолого-геофизических моделей литосферы крупных регионов, к которым относится Восточно-Европейский кратон (ВЕК), возможно только на основе комплексной интерпретации совокупности геофизических данных, поскольку обратные задачи геофизики для любого отдельно взятого метода не имеют единственного решения $[1,2]$. Развитие идей комплексной интерпретации геофизических данных, заложенное в работах [3-5], подразумевает использование критериально-целевого подхода к процедуре интерпретации, в рамках которого выполняется объединение решений каждого отдельного метода в некотором согласованном представлении для искомых физических параметров изучаемой среды. Основой для такого объединения являются феноменологические зависимости, выражающие взаимосвязи между различными петрофизическими свойствами пород, которые в общем случае носят не функциональный, а вероятностный характер [6-8 и др.]. Именно на основе такого подхода задачу комплексной интерпретации геофизических данных можно рассматривать как нахождение некоторого совместного согласованного решения для системы уравнений, описывающей принимаемый в рассмотрение комплекс геофизических полей, через искомые физические параметры среды [7, 9]. Эффективность данного подхода продемонстрирована на множестве примеров трёхмерных и двухмерных региональных построений геофизических моделей литосферы щитов и платформ [7, 9-15].

В рассмотренной постановке определяющую роль играет формализованное описание имеющейся геологической информации по изучаемому объёму среды. К такой информации относятся сведения о поверхностном геологическом строении региона исследований, включая геометрические характеристики блоков изучаемой среды, а также физические свойства слагающих их пород [7, 12, 13 и др.]. Именно наличие априорной геолого-геофизической и петрофизической информации позволяет получать реалистичные интерпретационные геофизические модели литосферы.

Важной составляющей в общей процедуре комплексного литосферного моделирования является построение термической модели [7, 10, 12 и др.], которая определяет вариации физических свойств пород в зависимости от температуры в изучаемой среде. При этом построение термической модели литосферы должно максимально учитывать известные тепловые свойства пород поверхностных геологических комп- лексов, что позволяет получать наиболее достоверные оценки глубинных температур в среде [7, 9, 16 и др.]. Именно в этом контексте ниже рассматриваются результаты обобщения новых данных о теплогенерации поверхностных пород кристаллического фундамента и проанализированы взаимосвязи этого параметра с составом и физическими свойствами типичных пород фундамента центральной части ВЕК.

\section{Исходные данные}

Геотермические исследования на территории центральной части ВЕК и прилегающих регионов выполняются достаточно давно и к настоящему времени накоплено большое количество результатов измерений, основная часть которых внесена в геотермическую базу данных [17, 18] Международной комиссии по тепловому потоку (IHFC-2021). Эта база данных включает координаты точек измерений, величины поверхностного теплового потока, теплопроводности пород, а также значения теплогенерации в породах среды. Причём последний параметр является наименее обеспеченным фактурными данными, поскольку измерения теплогенерации далеко не всегда сопровождают натурные геотермические исследования. Выборка фрагмента данных из базы IFHC-2021 для величин измеренного поверхностного теплового потока по области наших построений показана на рис. 1, вместе с привязкой к главным структурно-тектоническим единицам изучаемой территории по [19, 20]. Данные IFHC-2021, представленные на рисунке, демонстрируют существенную пространственную неоднородность точек измерения теплового потока в рамках изучаемой территории и, главное, весьма слабую обеспеченность натурных измерений теплогенерации пород. Для сравнения: общее количество точек с данными о тепловом потоке в приведённом фрагменте базы данных IFHC-2021 составляет 1264 измерения, а число точек с данными о теплогенерации пород - всего 36 , причём большая их часть приходится на территорию Украинского щита.

Отмеченная неоднородность и неполнота исходных геотермических данных вынуждает использовать весьма упрощённые подходы в термическом моделировании с усреднением теплового потока на крупных сетках и простейшими обобщёнными моделями распределения теплогенерации в земной коре, как например в [21]. Более содержательным для нашего региона является стохастическое моделирование температуры в литосфере, как это выполнено [22], с использованием деформируемых пространственных сеток и естественных ограничений на вариации теплогенерации в слоях модели. В общей постановке задача трёхмерного термического моделирования разрешима при условии достаточной полноты исходных данных о теплогенерации и теплопроводности пород слоёв литосферы [7]. Таким образом, привлечение новых результатов изучения теплогенерации поверхностных пород является важной частью геотермического моделирования, направленной на создание максимально полного и геологически адекватного описания входных параметров 
модели изучаемой среды

В прикладной геотермии оценка теплогенерации породы выполняется на основе определения концентрации долгоживущих изотопов теплогенерирующих элементов, к которым относятся ${ }^{40} \mathrm{~K},{ }^{232} \mathrm{Th},{ }^{235} \mathrm{U}$ и ${ }^{238} \mathrm{U}$. По данным о концентрации указанных элементов рассчитывается величина теплогенерации в породе, согласно выражению [23, 24]

$$
q=10^{-5} \cdot \rho \cdot\left(3.4302 \cdot C_{\mathrm{K}}+2.6368 \cdot C_{\mathrm{Th}}+9.8314 \cdot C_{\mathrm{U}}\right),
$$

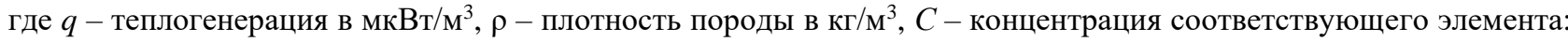
калия - в весовых процентах; тория и урана - в ppm. Коэффициенты в выражении (1) учитывают природное соотношение изотопов в общем процентном содержании соответствующего элемента в породе.

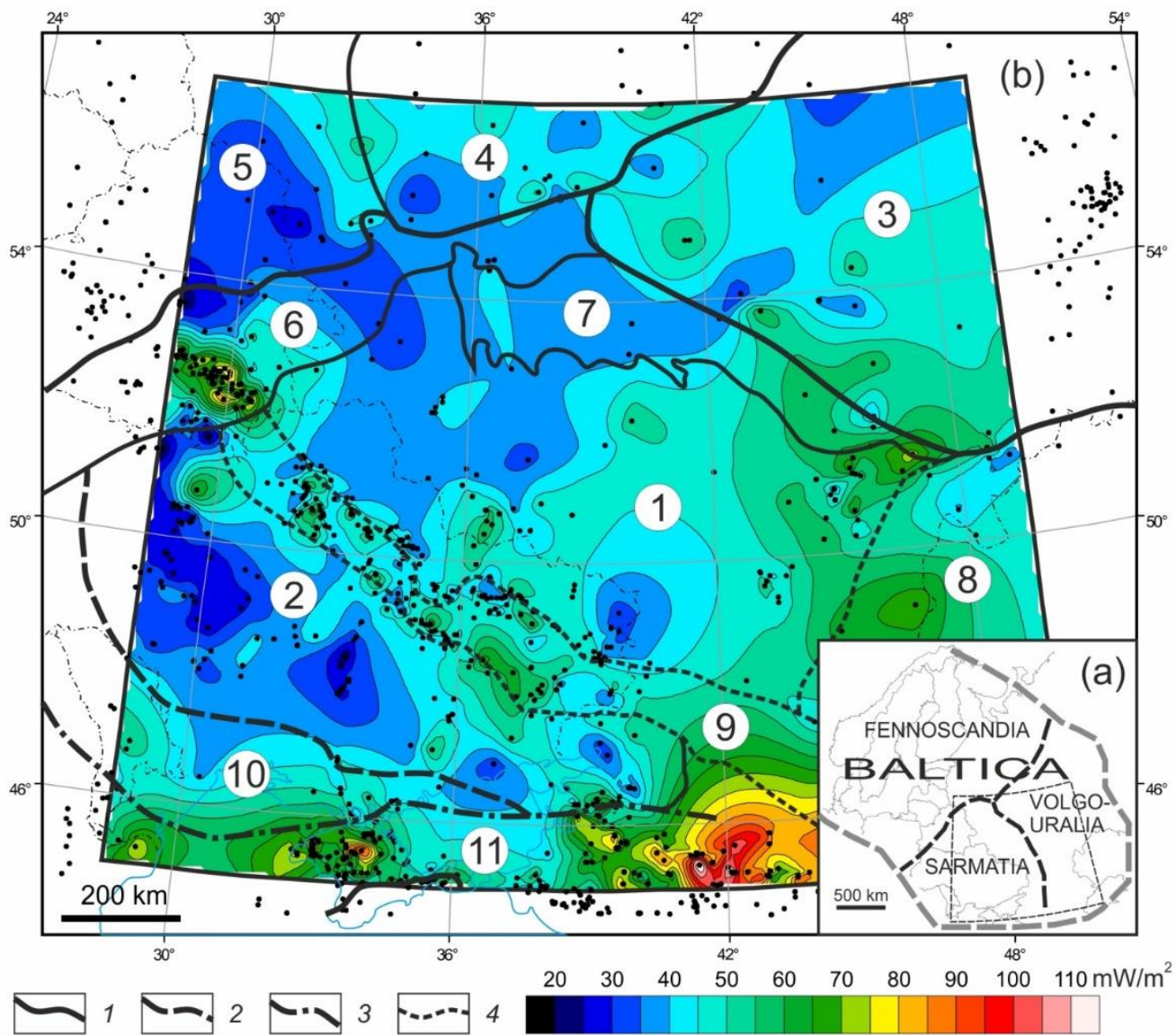

Рис. 1. (а) Обзорная схема кратона BALTICA по [19] (показано положение области исследований). (b) Карта поверхностного теплового потока по данным $[17,18]$ (показаны точки измерений) и главные тектонические структуры ВЕК по [20]. Условные обозначения: 1 - границы палеоконтинентов и орогенов; 2 - южное ограничение Украинского щита; 3 - граница раннедокембрийского фундамента ВЕК; 4 - границы неопротерозой-фанерозойских впадин. Цифрами обозначены: Воронежский кристаллический массив (1), Украинский щит (2), Волго-Уралия (3), Лапландско-Среднерусский ороген (4), Южно-Прибалтийский ороген (5), Осницко-Микашевичский пояс (6), Северо-Воронежский ороген (7); Прикаспийская впадина (8), Днепрово-Донецкая впадина (9), Причерноморская впадина (10), Скифская плита (11).

[Fig. 1. (a) Overview scheme of the BALTICA craton according to [19] (shows the position of the area of research). (b) Map of the surface heat flow according to data $[17,18]$ (measurement points shown) and main tectonic structures of the EEC according to [20]. Legend: (1) - boundaries of paleocontinents and orogens; (2) - southern restriction of the Ukrainian shield; (3) - boundary of the Early Cambrian basement of the EEC; (4) - boundaries of the Neoproterozoic-Phanerozoic depressions. Numbers: Voronezh Crystalline Massive (1), Ukrainian Shield (2), Volgo-Uralia (3), Lapland-Central Russian orogen (4), South Baltic orogen (5), Osnitsko-Mikashevichi belt (6), North Voronezh orogen (7); Caspian depression (8), Dnieper-Donets depression (9), Black Sea depression (10), Scythian plate (11).]

Собственно определение содержания теплогенерирующих элементов в образцах пород выполняются рентген-флуоресцентным или гамма-спектрометрическим методом $[23,25]$. В последнее время для оценки величин теплогенерации пород привлекаются результаты анализа валовых проб содержаний редких и рассеянных элементов методом индуктивно-связанной плазменной масс-спектрометрии (ICP-MS), которые часто используются при модельных петрогенетических построениях. Анализ точности получаемых результатов по содержанию теплогенерирующих элементов, приведённый в [26], демонстрирует высокое качество оценок теплогенерации пород на основе данных ICP-MS. 
Ниже рассмотрим результаты валового анализа содержаний теплогенерирующих элементов методом ICP-MS для образцов типичных пород фундамента крупных тектонических единиц ВЕК, которые в большом количестве были получены в последние три десятилетия разными авторами. Поскольку основной задачей исследования является оценка теплогенерации пород ВЕК, то в сводных данных результатов ICP-MS из опубликованных работ, нами рассматривалось только содержание калия, тория и урана. Причём содержания этих элементов, при необходимости, приводились к абсолютным значениям концентраций с учётом использованных авторами публикаций моделей примитивной мантии [27-29]. Помимо концентраций теплогенерирующих элементов в исходных данных анализировалось валовое содержание кремнезёма $\left(\mathrm{SiO}_{2}\right)$, которое представляет интерес для выявления связей величин теплогенерации и основности пород.

Сводка использованных результатов ICP-MS по содержанию теплогенерирующих элементов в породах докембрийского фундамента изучаемой территории и её обрамления даётся в таблице 1. Геологическая привязка объектов исследования приводится в таблице по данным авторов цитируемых публикаций, а для объектов на территории Воронежского кристаллического массива (ВКМ) кроме того даётся по легенде геологической карты [30]. Как явствует из данных таблицы 1, основная часть первичных результатов анализов ICPMS приходится на территорию ВКМ. Для территории Украинского щита (УЩ) имеется существенно меньше данных о содержании радиогенных элементов в породах фундамента, а для прилегающих регионов Волго-Уралии и Фенноскандии такие данные ещё более редки.

Таблица 1. Использованные первичные данные

[Table 1. The used primary data]

\begin{tabular}{|c|c|c|c|c|}
\hline $\begin{array}{c}\text { Геологическая единица } \\
\text { [Geological unit] }\end{array}$ & $\begin{array}{l}\text { Объект } \\
\text { [Object] }\end{array}$ & $\begin{array}{l}\text { Возраст, млн. } \\
\text { лет [Age, mil- } \\
\text { lion years] }\end{array}$ & $\begin{array}{r}\text { Породы } \\
\text { [Rocks] }\end{array}$ & $\begin{array}{c}\text { Источник } \\
\text { данных } \\
\text { [Data source] }\end{array}$ \\
\hline 1 & 2 & 3 & 4 & 5 \\
\hline \multicolumn{5}{|c|}{ ВKM [VKM] } \\
\hline $\begin{array}{l}\text { Усманский комплекс } \\
\text { [The Usman complex] }\end{array}$ & $\begin{array}{l}\text { Массивы: Усманский, Да- } \\
\text { выдовский, Девицкий, } \\
\text { Тербуновский, Двуречен- } \\
\text { ский, Сомовский (Ново- } \\
\text { усманский), Костенков- } \\
\text { ский } \\
\text { [Massifs: Usman, Da- } \\
\text { vydovka, Devitsa, Terbuny, } \\
\text { Dvurechensk, Somovo (No- } \\
\text { vaya Usman), Kostenky] }\end{array}$ & $\begin{array}{l}2047 \pm 11 \\
2085 \pm 9 \\
2097 \pm 3\end{array}$ & $\begin{array}{l}\text { Трондьемиты, гранодиориты, } \\
\text { тоналиты, граниты, мигматиты } \\
\text { [Trondhjemites, granodiorites, } \\
\text { tonalites, granites, migmatites] }\end{array}$ & [31-34] \\
\hline $\begin{array}{l}\text { Павловский комплекс } \\
\text { [The Pavlovsk complex] }\end{array}$ & $\begin{array}{l}\text { Массивы: Павловский, } \\
\text { Хохольский, Репьёвский, } \\
\text { Лискинский, Россошан- } \\
\text { ский, Олым } \\
\text { [Massifs: Pavlovsk, } \\
\text { Khokhol, Repyevka, Liski, } \\
\text { Rossosh, Olym] }\end{array}$ & $\begin{array}{l}2078 \pm 4 \\
2067 \pm 8 \\
2081 \pm 7 \\
2077 \pm 11 \\
2064 \pm 14 \\
2063 \pm 9\end{array}$ & $\begin{array}{l}\text { Граниты, лейкограниты, грано- } \\
\text { диориты, монцограниты, гра- } \\
\text { носиениты } \\
\text { [Granites, leucogranites, } \\
\text { granodiorites, monzogranites, } \\
\text { granosyenites] }\end{array}$ & $\begin{array}{l}{[32,33,35,} \\
36]\end{array}$ \\
\hline $\begin{array}{l}\text { Бобровский комплекс } \\
\text { [The Bobrov complex] }\end{array}$ & $\begin{array}{l}\text { Массивы: Бобровский, Та- } \\
\text { ловский, Красненский, Ро- } \\
\text { мановский, Терновский, } \\
\text { Ворошиловский, Коршев- } \\
\text { ской, Панинский } \\
\text { [Massifs: Bobrov, } \\
\text { Talovaya, Krasnoye, Roma- } \\
\text { novka, Ternovoye, Voroshi- } \\
\text { lovsky, Korshevo, Panino] }\end{array}$ & $\begin{array}{l}2063 \pm 6 \\
2058 \pm 11 \\
2055 \pm 7 \\
2050 \pm 13 \\
2067 \pm 10\end{array}$ & $\begin{array}{l}\text { Граниты, кварцевые мон- } \\
\text { цониты } \\
\text { [Granites, quartz monzonites] }\end{array}$ & {$[33,36-39]$} \\
\hline $\begin{array}{l}\text { Воронежская свита } \\
\text { [Voronezh suite] }\end{array}$ & $\begin{array}{l}\text { Грабены: Байгора и Калач } \\
\text { [Grabens Baygora and } \\
\text { Kalach] }\end{array}$ & $\begin{array}{l}2047 \pm 17 \\
2050 \pm 16\end{array}$ & $\begin{array}{l}\text { Андезиты, андезибазальты } \\
\text { [Andesites, basaltic andesites] }\end{array}$ & {$[32,40,41]$} \\
\hline $\begin{array}{l}\text { Воронцовский ком- } \\
\text { плекс } \\
\text { [The Vorontsovo } \\
\text { complex] }\end{array}$ & $\begin{array}{l}\text { Нижняя и средняя толщи } \\
\text { [Lower and medium strata] }\end{array}$ & $2100-2200$ & $\begin{array}{l}\text { Сланцы, метапесчаники } \\
\text { [Shale, metasandstone] }\end{array}$ & {$[32,42]$} \\
\hline $\begin{array}{l}\text { Рожденственский ком- } \\
\text { плекс } \\
\text { [The Rozhdestvensky } \\
\text { complex] }\end{array}$ & $\begin{array}{l}\text { Массивы: Репнинский, Рa- } \\
\text { монский } \\
\text { [Massifs: Repnoye, Ramon] }\end{array}$ & $\begin{array}{l}2120 \pm 11 \\
2158 \pm 43\end{array}$ & $\begin{array}{l}\text { Габбродиориты, монцограни- } \\
\text { тоиды } \\
\text { [Gabbrodiorites, } \\
\text { monzogranitoids] }\end{array}$ & [43] \\
\hline
\end{tabular}


Продолжение Табл. 1

[Continued Table 1]

\begin{tabular}{|c|c|c|c|c|}
\hline 1 & 2 & 3 & 4 & 5 \\
\hline $\begin{array}{l}\text { Ольховский комплекс } \\
\text { [The Olkhovsky com- } \\
\text { plex] }\end{array}$ & $\begin{array}{l}\text { Ольховский кольцевой } \\
\text { массив } \\
\text { [Olkhovsky ring massif] }\end{array}$ & $\begin{array}{l}2070 \pm 9 \\
2044 \pm 13\end{array}$ & $\begin{array}{l}\text { Гранодиориты, трондъемиты, } \\
\text { монцониты, монцодиориты } \\
\text { [Granodiorites, trondhjemites, } \\
\text { monzonites, monzodiorites] }\end{array}$ & {$[41,44]$} \\
\hline $\begin{array}{l}\text { Мамонский комплекс } \\
\text { [The Mamon complex] }\end{array}$ & $\begin{array}{l}\text { Елань-Коленовский плу- } \\
\text { тон } \\
\text { [Yelan-Koleno pluton] }\end{array}$ & $2080 \pm 20$ & $\begin{array}{l}\text { Габбро-нориты, габбро-дио- } \\
\text { риты, пироксениты, перидо- } \\
\text { титы } \\
\text { [Gabbro-norites, gabbro-diorites, } \\
\text { pyroxenites, peridotites] }\end{array}$ & {$[45]$} \\
\hline $\begin{array}{l}\text { Еланский комплекс } \\
\text { [The Yelan complex] }\end{array}$ & $\begin{array}{l}\text { Массив Ёлка } \\
\text { [Yolka massif] }\end{array}$ & $2060 \pm 20$ & $\begin{array}{l}\text { Diorites, norites, monzodiorites } \\
\text { [Диориты, нориты, монцодио- } \\
\text { риты] }\end{array}$ & [46] \\
\hline $\begin{array}{l}\text { Лосевская серия } \\
\text { [Losevo series] }\end{array}$ & $\begin{array}{l}\text { Толщи: Подгоренская, } \\
\text { Стрелицкая } \\
\text { [Strata: Podgornoye, } \\
\text { Strelitsa] }\end{array}$ & $\begin{array}{l}2168 \pm 11 \\
2134 \pm 8\end{array}$ & $\begin{array}{l}\text { Метариолиты, метабазальты, } \\
\text { андезиты, туфы, вулканогенно- } \\
\text { осадочные породы, толеиты, } \\
\text { риолиты } \\
\text { [Metariolites, metabasalts, ande- } \\
\text { sites, tuffs, volcanic-sedimentary } \\
\text { rocks, tholeiites, riolites] }\end{array}$ & {$[32,47-49]$} \\
\hline $\begin{array}{l}\text { Обоянский плутоно-ме- } \\
\text { таморфический ком- } \\
\text { плекс } \\
\text { [The Oboyan pluton- } \\
\text { metamorphic complex] }\end{array}$ & $\begin{array}{l}\text { Курский блок, Донская ас- } \\
\text { социация } \\
\text { [Kursk Block, Don } \\
\text { association] }\end{array}$ & $\begin{array}{l}3535-3556 \\
3464-3472 \\
3334-3384\end{array}$ & $\begin{array}{l}\text { TTG, metagabbro, metapelitic } \\
\text { granulites, ferrugenous-silicious } \\
\text { formations } \\
\text { [ТТГ, метагаббро, метапелито- } \\
\text { вые гранулиты, ЖКФ] }\end{array}$ & $\begin{array}{l}{[32,36,50,} \\
51]\end{array}$ \\
\hline $\begin{array}{l}\text { Стойло-Николаевский } \\
\text { комплекс } \\
\text { [The Stoylo-Nikolaevsky } \\
\text { complex] }\end{array}$ & $\begin{array}{l}\text { Массивы: Екатеринов- } \\
\text { ский, Роговский, Северо- } \\
\text { Щигровский, Троснян- } \\
\text { ский } \\
\text { [Massifs: Yekaterinovka, } \\
\text { Rogovo, North Shchigry, } \\
\text { Trosna] }\end{array}$ & $\begin{array}{l}2085 \pm 5 \\
2045 \pm 15 \\
2049 \pm 10 \\
2058 \pm 7\end{array}$ & $\begin{array}{l}\text { Гранодиориты, диориты } \\
\text { [Granodiorites, diorites] }\end{array}$ & {$[52,53]$} \\
\hline Тимская свита & $\begin{array}{l}\text { Тим-Ястребовская струк- } \\
\text { тура } \\
\text { [Tim-Yastrebovo structure] }\end{array}$ & $2099 \pm 8$ & $\begin{array}{l}\text { Сланцы, метапесчаники, квар- } \\
\text { циты, силикатно-карбонатные } \\
\text { породы, метабазиты } \\
\text { [Shale, metasandstone, quarzites, } \\
\text { silicate-carbonate rocks, } \\
\text { metabasites] }\end{array}$ & {$[54-57]$} \\
\hline $\begin{array}{l}\text { Лебединская свита } \\
\text { [Lebedinskoye suite] }\end{array}$ & $\begin{array}{l}\text { Тим-Ястребовская струк- } \\
\text { тура } \\
\text { [Tim-Yastrebovo structure] }\end{array}$ & $2612 \pm 10$ & $\begin{array}{l}\text { Риолиты } \\
\text { [Riolites] } \\
\end{array}$ & {$[58]$} \\
\hline $\begin{array}{l}\text { Салтыковский комплекс } \\
\text { [The Saltykovka } \\
\text { complex] }\end{array}$ & $\begin{array}{l}\text { Салтыковский массив и } \\
\text { его аналоги } \\
\text { [Saltykovska massif and its } \\
\text { analogues] }\end{array}$ & $2960-3050$ & $\begin{array}{l}\text { TTГ } \\
{[\mathrm{TTG}]}\end{array}$ & [59] \\
\hline $\begin{array}{l}\text { Курбакинская свита } \\
\text { [Kurbakino suite] }\end{array}$ & $\begin{array}{l}\text { Михайловская структура } \\
\text { [Mikhailovka structure] }\end{array}$ & $2065-2047$ & $\begin{array}{l}\text { Дациты, риолиты, базальты } \\
\text { [Dacites, riolites, basalts] }\end{array}$ & {$[60,61]$} \\
\hline $\begin{array}{l}\text { Игнатеевская свита } \\
\text { [Ignatievo suite] }\end{array}$ & $\begin{array}{l}\text { Михайловская структура } \\
\text { [Mikhailovka structure] }\end{array}$ & & $\begin{array}{l}\text { Доломиты, известково-сили- } \\
\text { катные породы, метапесча- } \\
\text { ники, метаконгломераты } \\
\text { [Dolomites, calcareous-silicate } \\
\text { rocks, metasandstones, meta- } \\
\text { conglomerates] }\end{array}$ & {$[62,63]$} \\
\hline $\begin{array}{l}\text { Золотухинский ком- } \\
\text { плекс } \\
\text { [The Zolotukhino } \\
\text { complex] }\end{array}$ & $\begin{array}{l}\text { Гнилушенский массив } \\
\text { [Gnilusha massif] }\end{array}$ & $2063 \pm 12$ & $\begin{array}{l}\text { Габброиды } \\
\text { [Gabbroids] }\end{array}$ & [52] \\
\hline $\begin{array}{l}\text { Атаманский комплекс } \\
\text { [The Ataman complex] }\end{array}$ & $\begin{array}{l}\text { Атаманский массив } \\
\text { [Ataman massif] }\end{array}$ & $2612 \pm 6$ & $\begin{array}{l}\text { Граниты } \\
\text { [Granites] }\end{array}$ & {$[58,64]$} \\
\hline $\begin{array}{l}\text { Глазуновская свита } \\
\text { [Glazunovskaya suite] }\end{array}$ & $\begin{array}{l}\text { Орловская структура } \\
\text { [Orlovskaya structure] }\end{array}$ & $2067 \pm 5$ & $\begin{array}{l}\text { Андезитовые порфириты } \\
\text { [Andesite porphyrites] }\end{array}$ & {$[65,66]$} \\
\hline
\end{tabular}


Продолжение Табл. 1

[Continued Table 1]

\begin{tabular}{|c|c|c|c|c|}
\hline \multicolumn{5}{|c|}{ Волго-Уралия [Volgo-Uralia] } \\
\hline $\begin{array}{l}\text { Центральная и южная } \\
\text { Волго-Уралия } \\
\text { [Central and Southern } \\
\text { Volgo-Uralia] }\end{array}$ & $\begin{array}{l}\text { Больше-черемшанская се- } \\
\text { рия } \\
\text { [Bolshoy Cheremshan } \\
\text { series] }\end{array}$ & $2470-3170$ & $\begin{array}{l}\text { Метаосадки, мигматиты, мета- } \\
\text { вулканиты, гнейсы, сланцы } \\
\text { [Metasediments. migmatites, } \\
\text { metavolcanics, gneisses, shales] }\end{array}$ & {$[67-69]$} \\
\hline $\begin{array}{l}\text { Волго-Уралия } \\
\text { [Volgo-Uralia] }\end{array}$ & $\begin{array}{l}\text { Волго-Донской ороген } \\
\text { [Volga-Don orogeny] }\end{array}$ & $\begin{array}{l}3140 \pm 7 \\
3127 \pm 46\end{array}$ & $\begin{array}{l}\text { Эндербиты, чарнокиты, тона- } \\
\text { литы } \\
\text { [Enderbites, charnockite, tonali- } \\
\text { ties] }\end{array}$ & [70] \\
\hline $\begin{array}{l}\text { Воронцовский ком- } \\
\text { плекс } \\
\text { [The Vorontsovo } \\
\text { complex] }\end{array}$ & $\begin{array}{l}\text { Массивы: Артюшки, Гу- } \\
\text { cиха } \\
\text { [Massifs: Artyushki, } \\
\text { Gusikha] }\end{array}$ & $\begin{array}{l}524 \pm 3 \\
514 \pm 2\end{array}$ & $\begin{array}{l}\text { Сиениты, монцониты } \\
\text { [Syenites, monzonites] }\end{array}$ & [71] \\
\hline \multicolumn{5}{|c|}{ УЩ [Ukrainian Shield] } \\
\hline $\begin{array}{l}\text { Приазовский террейн } \\
\text { [Pryazovia terrain] }\end{array}$ & $\begin{array}{l}\text { Салтычанский антиклино- } \\
\text { рий } \\
\text { [Saltych anticlinorium] }\end{array}$ & $\begin{array}{l}2911 \pm 5 \\
2920 \pm 13 \\
2925 \pm 8 \\
2941 \pm 9 \\
\end{array}$ & $\begin{array}{l}\text { Габбро, горнблендиты, габбро- } \\
\text { диориты, диориты } \\
\text { [Gabbro, hornblendites, } \\
\text { gabbrodiorites, diorites] }\end{array}$ & {$[72,73]$} \\
\hline $\begin{array}{l}\text { Северо-западный блок } \\
\text { [Northwestern block] }\end{array}$ & $\begin{array}{l}\text { Коростенский плутон } \\
\text { [Korosten pluton] }\end{array}$ & $\begin{array}{l}1740-1800 \\
1761 \pm 13\end{array}$ & $\begin{array}{l}\text { Анортозиты, риолиты, рапа- } \\
\text { киви } \\
\text { [Anorthosites, riolites, rapakivi] }\end{array}$ & {$[74-76]$} \\
\hline $\begin{array}{l}\text { Средне-приднепров- } \\
\text { ский и Приазовский ме- } \\
\text { габлоки } \\
\text { [Middle Dnieper and } \\
\text { Priazovia megablocks] }\end{array}$ & $\begin{array}{l}\text { Зеленокаменные пояса } \\
\text { [Greenstone belts] }\end{array}$ & $\begin{array}{l}3000-3100 \\
3300-3600\end{array}$ & $\begin{array}{l}\text { Метапесчаники, кварциты, } \\
\text { сланцы } \\
\text { [Metasandstones, quarzites, } \\
\text { shales] }\end{array}$ & {$[77,78]$} \\
\hline $\begin{array}{l}\text { Подольский домен } \\
\text { [Podolsk domain] }\end{array}$ & $\begin{array}{l}\text { Днестрово-бугская форма- } \\
\text { ция } \\
\text { [The Dniestr-Bug } \\
\text { formation] }\end{array}$ & $3650-3750$ & $\begin{array}{l}\text { Эндербиты, метаосадки, } \\
\text { гнейсы } \\
\text { [Enderbites, metasediments, } \\
\text { gneisses] }\end{array}$ & [79] \\
\hline $\begin{array}{l}\text { Дайковый комплекс } \\
\text { УЩ } \\
\text { [The dyke complex of the } \\
\text { Ukrainian Shield] }\end{array}$ & $\begin{array}{l}\text { Плутоны: Коростенский, } \\
\text { Корсунь-Новомиргород- } \\
\text { ский. Азовский блок } \\
\text { [Plutons: Korosten, Korsun- } \\
\text { Novomirgorod Azov block] }\end{array}$ & $1750-1800$ & $\begin{array}{l}\text { Долериты субщелочные доле- } \\
\text { риты } \\
\text { [Dolerites, subalkaline dolerites] }\end{array}$ & {$[80,81]$} \\
\hline $\begin{array}{l}\text { Днестер-Буг домен } \\
\text { [The Dniestr-Bug do- } \\
\text { main] }\end{array}$ & $\begin{array}{l}\text { Гранулитовая дуга } \\
\text { [Granulite arc] }\end{array}$ & $\begin{array}{l}3550 \pm 31 \\
3612 \pm 38\end{array}$ & $\begin{array}{l}\text { Эндербиты, гранулиты } \\
\text { [Enderbites, granulites] }\end{array}$ & {$[82]$} \\
\hline \multicolumn{5}{|c|}{ Свекофенниды [Svekofennides] } \\
\hline $\begin{array}{l}\text { Южно-Прибалтийский } \\
\text { opоген } \\
\text { [South Baltic orogeny] }\end{array}$ & $\begin{array}{l}\text { Деформационная зона } \\
\text { Телсиаи } \\
\text { [Telsiai Deformation Zone] }\end{array}$ & $\begin{array}{l}1625 \pm 6 \\
1619 \pm 27\end{array}$ & $\begin{array}{l}\text { Гранодиориты, чарнокиты } \\
\text { [Granodiorites, charnockites] }\end{array}$ & [83] \\
\hline
\end{tabular}

\section{Оценка теплогенерации пород фундамента}

На основе исходных материалов по содержанию радиогенных элементов был выполнен расчёт теплогенерации пород фундамента изучаемой территории согласно выражению (1). Для оценки величин теплогенерации использовались детальные сведения о плотности пород фундамента ВКМ [84] и менее детальные материалы по плотности пород Украинского щита, Волго-Уралии и Фенноскандии [85-88]. Привязка конкретных точек определения концентрации радиогенных элементов к соответствующим комплексам пород, а равно и величинам их плотности, выполнялась на основе геологических карт фундамента изучаемой территории [30, 89], представленных в ГИС ArcView. Как результат была сформирована атрибутивная база данных содержащая: пространственные координаты точек анализов ICP-MS, величины концентрации радиогенных элементов, содержание кремнезёма, плотностные характеристики породы и расчётные данные о теплогенерации. Отметим, что все использованные физические величины описываются их средними значениями и диапазонами вариаций соответствующих параметров.

Пространственное положение результативных точек сформированной базы данных по теплогенерации пород кристаллического фундамента изучаемого региона приведено на рис. 2. По сравнению с имеющимися для нашей территории данными IHFC-2021 [17, 18], также показанными на рисунке, новые результаты оценок теплогенерации пород фундамента существенно расширяют и уточняют важную геотермическую характеристику пород верхней части докембрийской коры региона. 


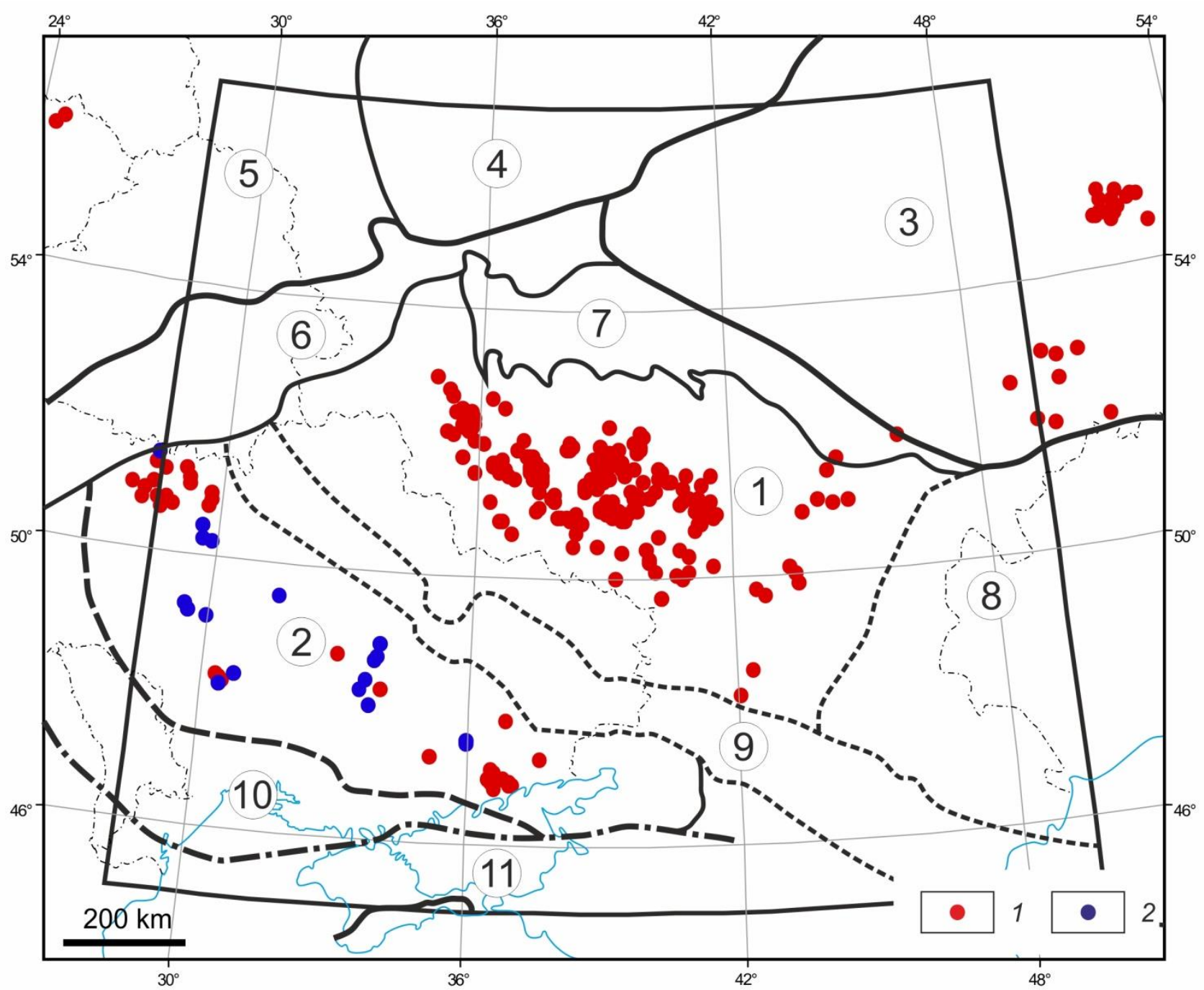

Рис. 2. Точки с данными о теплогенерации пород фундамента центральной части ВЕК (тектонические структуры см. рис. 1.) Условные обозначения: 1 - наши результаты; 2 - данные IHFC-2021 [17, 18].

[Fig. 2. Points with data on heat generation of the basement rocks of the central part of the EEC (tectonic structures, see Fig. 1.). Legend: (1) - our results; (2) - IHFC-2021 data [17, 18].]

Как явствует из рис. 2, пространственное распределение точек с данными о величинах теплогенерации является достаточно неоднородным. В силу этого создание общей цифровой схемы распределения величин теплогенерации поверхностных кристаллических пород можно выполнить, опираясь на геологические сведения о строении фундамента региона [30, 89]. Кроме того, при построении схемы «петротеплогенерации» фундамента следует принимать во внимание возможную корреляцию значений теплогенерации пород с их химическим составом (в первую очередь с содержанием кремнезёма) и плотностью пород. Подобная схема петротеплогенерации будет характеризовать верхнюю наиболее неоднородную часть докембрийского фундамента, распространяющуюся до нижней границы гравиактивного слоя региона [90]. В целом, построение схемы теплогенерации пород верхней коры представляет важный элемент геотермического моделирования [7, 12-14, 22] на стадии создания начального приближения модели среды.
Ниже рассмотрим более подробно выявление указанных связей между величинами теплогенерации и физико-химическими характеристиками пород фундамента ВКМ, для которых нами составлена представительная база первичных данных.

\section{Анализ данных и обсуждение}

Для территории ВКМ была сформирована отдельная выборка первичных материалов из сводной базы данных, представленной в геоинформационной системе ArcView для всего региона исследований. Выборка содержит данные о концентрации радиогенных элементов и содержании кремнезёма в точках отбора образцов (см. источники данных в табл. 1), плотностные характеристики соответствующего комплекса пород по [84] и расчётные данные о теплогенерации пород согласно выражению (1). Все использованные физические величины описываются их средними (модальными) значениями и диапазонами вариаций соответствующих параметров. 
Сводная статистика распределения усреднённых данных о теплогенерации пород фундамента ВКМ, представленная на рис. 3 , показывает, что значения теплогенерации пород фундамента ВКМ варьируют в диапазоне от 0.1 до $7.54 \mathrm{M \kappa BT} / \mathrm{M}^{3}$ со средним значением 0.528 мкВт/м ${ }^{3}$. Распределение теплогенерации пород является приблизительно логарифмически-нормальным. Минимальные величины теплогенерации относятся к железистым кварцитам и известково-силикатным породам игнатеевской свиты, в то время как максимальные значения теплогенерации характерны для субщелочных гранитоидов и лейкогранитов павловского комплекса. Среднее значение величины теплогенерации пород ВКМ соответствует таковому для пород

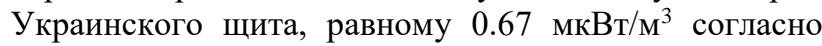
данным IHFC-2021 [17, 18], хотя такое сопоставление для выборок, различающихся по объёму почти в пятьдесят раз (см. рис. 2), не вполне корректно. Необходимо отметить, что наши результаты для территории ВКМ отличаются от усреднённых данных по континентальной коре Земли [26, 91], где оценка теплогенерации для верхней коры составляет $1.66 \pm 0.17$ мкВт/м ${ }^{3}$, а для средней коры $0.99 \pm 0.11$ мкВт/м ${ }^{3}$. Очевидно, что наши оценки теплогенерации относятся к существенно более древним породам (архей, протерозой) и скорее всего, соответствуют средней коре в модели [91].

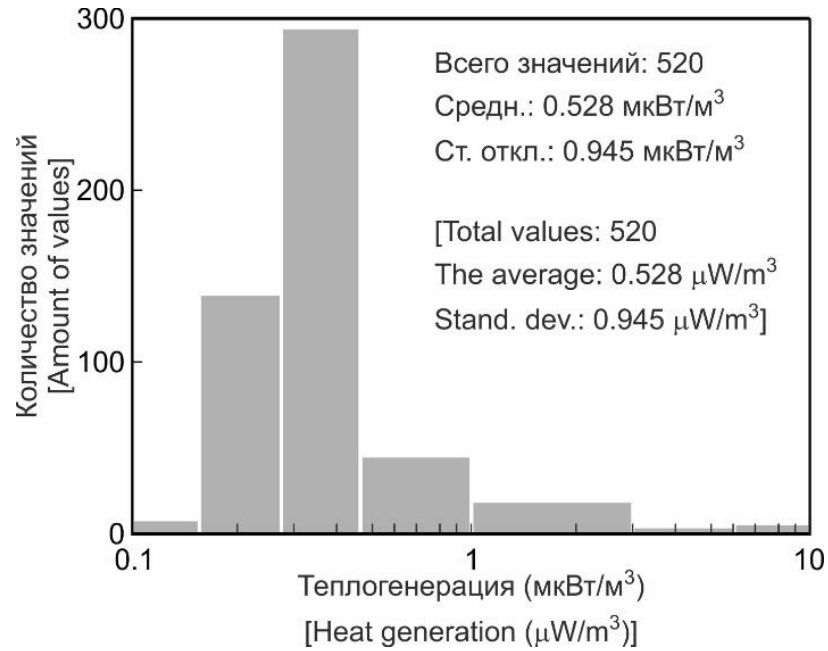

Рис. 3. Гистограмма рассчитанных значений теплогенерации пород фундамента ВКМ.

[Fig. 3. Histogram of calculated values of heat generation for VCM basement rocks.]

Исследование возможной взаимосвязи между значениями плотности пород фундамента ВКМ и рассчитанными величинами их теплогенерации (рис. 4) показало отсутствие корреляции между этими параметрами. Отметим, что в таком анализе из общей выборки были исключены семь точек данных с высокими величинами теплогенерации и низкими плотностями, отвечающие субщелочным гранитоидам. К такому же выводу об отсутствии связи пришли и авторы [92], проанализировавшие глобальные данные по теплогенерации гранитных пород Земли. В нашем случае, отсутст- вие корреляционной связи между плотностью и теплогенерацией не позволяет впрямую использовать материалы петроплотностной карты [84] для оценки теплогенерации комплексов пород фундамента ВКМ. При этом полученные данные по региону ВКМ не исключают возможности использования генерализованной взаимосвязи между скоростью продольных волн и теплогенерацией пород [7, 22], которые используются при термическом моделировании литосферы.

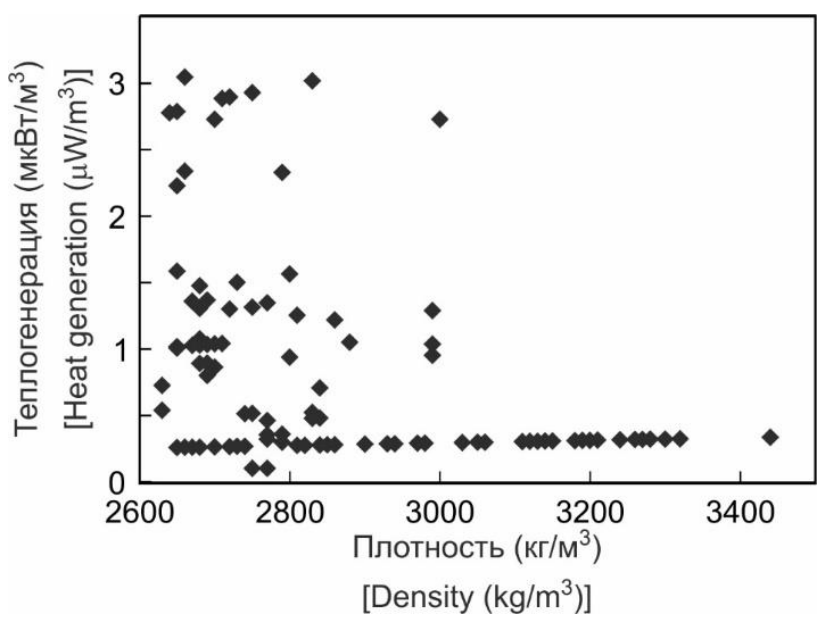

Рис. 4. Корреляция плотности и рассчитанных значений теплогенерации для пород фундамента ВКМ.

[Fig. 4. Correlation of density and calculated values of heat generation for VCM basement rocks.]

Важным аспектом взаимосвязи физических свойств и химического состава пород является корреляционная зависимость теплогенерации от основности породы, определяемой по среднему валовому содержанию кремнезёма. Такая зависимость, представленная на рис. 5, демонстрирует достоверную связь содержания $\mathrm{SiO}_{2}$ и величины рассчитанной теплогенерации пород, которая описывается экспоненциальным соотношением вида

$$
q\left(C_{\mathrm{SiO}_{2}}\right)=0.0092 \cdot \exp \left(0.0744 \cdot C_{\mathrm{SiO}_{2}}\right),
$$

где $q$ - теплогенерация в мкВт/м ${ }^{3}, C_{\mathrm{SiO}_{2}}-$ валовое содержание кремнезёма в \%. Отметим, что данная корреляционная связь получена при исключении из общей выборки семи точек с высокими величинами теплогенерации, характерными для субщелочных гранитоидов и лейкогранитов, а также восьми точек с содержанием кремнезёма менее $20 \%$, характерных для известковосиликатных пород игнатеевской свиты. Выявленная связь для пород фундамента ВКМ отвечает общей тенденции увеличения содержаний $\mathrm{U}, \mathrm{Th}$ и $\mathrm{K}$, а равно и величины теплогенерации, с уменьшением основности породы [7, 26, 93, 94]. В целом установленное корреляционное соотношение (2), связывающее теплогенерацию и основность пород фундамента ВКМ, позволяет переходить от химического состава породы к её теплотворной способности. Очевидно, что наши расчётные данные, приведённые на рис. 5, описывают не только 
саму корреляционную связь, но и меру её неопределённости, характеризуемую величиной энтропии условной плотности вероятности распределения рассматриваемых параметров [7, 22], с учётом их предварительного робастного оценивания по методу [95].

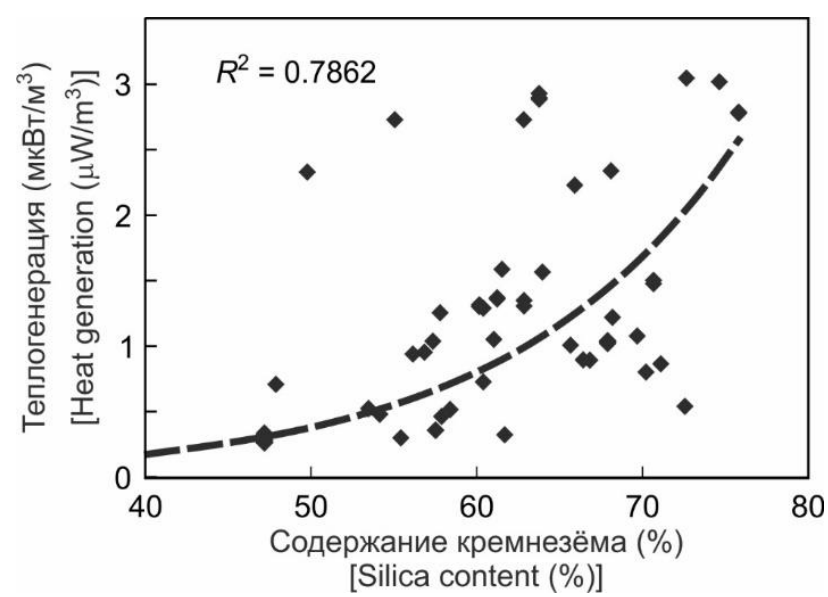

Рис. 5. Корреляция содержания кремнезёма и рассчитанных значений теплогенерации для пород фундамента ВКМ $\left(R^{2}-\right.$ величина достоверности аппроксимации).

[Fig. 5. Correlation of silica content and calculated heat generation values for VCM basement rocks $\left(\mathrm{R}^{2}\right.$ - approximation confidence value).]

Рассмотрим также зависимость теплогенерации от плотности для обобщённых групп пород, которые были сформированы из выборки данных, опираясь на классификацию типов пород фундамента ВКМ (табл. 1). Такая зависимость, приведённая на рис. 6, показывает общую тенденцию связи теплогенерации и плотности для обобщённых групп пород, различающихся по основности. Фактически эта взаимосвязь в опосредованной форме отражает результаты, показанные на рис. 5, однако детали соотношений параметров достаточно сложны и области теплогенерации и плотности для групп пород на рис. 6 существенно перекрываются. В целом полученные нами взаимосвязи хорошо согласуются с данными аналогичного анализа для интрузивных и вулканогенных пород мира [26, 9294], а также кристаллических пород верхней коры Фенноскандии [7]. Отметим, что использование выявленной классификации для групп пород фундамента ВКМ по соотношению теплогенерации и плотности, можно рекомендовать только на качественном уровне, как некоторую грубую оценку реальной ситуации.

Помимо приведённых выше результатов анализа, представляется интересным проверить зависимость теплогенерации кристаллических пород от их возраста, которая по данным авторов $[92,96,97]$ характерна для некоторых специфических условий. В нашем случае для пород ВКМ, обеспеченных данными ICP$\mathrm{MS}$, имеются немногим более шестидесяти значения возрастов с соответствующими оценками точности их определения (см. табл. 1). Эти результаты, также включённые в общую базу данных, позволили построить приближённую диаграмму связи между возрастом и

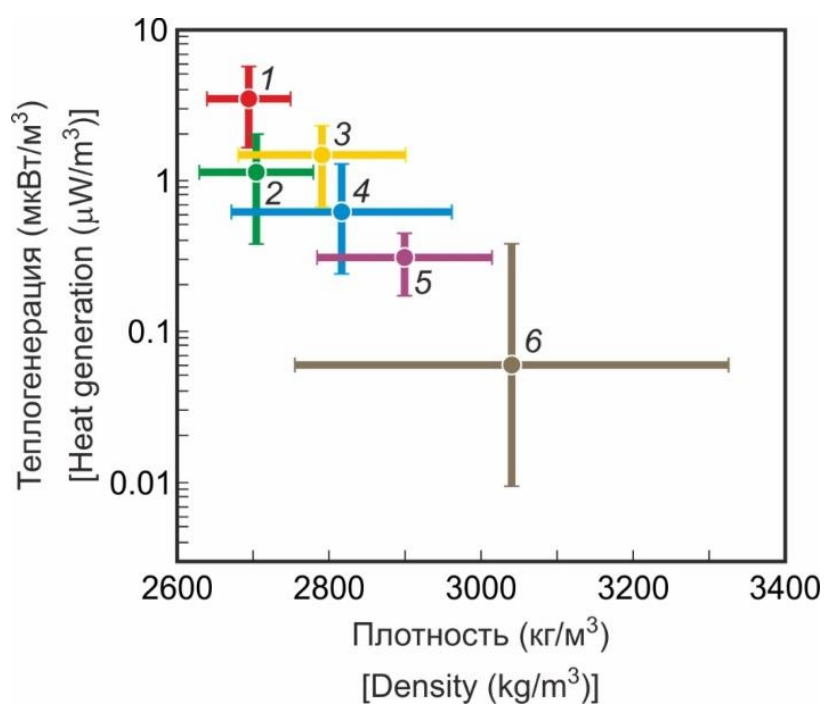

Рис. 6. Теплогенерация для типов пород фундамента ВКМ в зависимости от их плотности (показаны диапазоны изменений параметров). Условные обозначения: 1 - гранитоиды; 2 диориты, ТТГ; 3 - сланцы, метаосадочные породы; 4 - габброиды; 5 - нориты; 6 - кварциты, железистые кварциты, известково-силикатные породы.

[Fig. 6. Heat generation for types of VCM basement rocks depending on their density (ranges of parameter changes are shown). Legend: (1) - granitoids; (2) - diorites, TTG; (3) - shale, meta-sediment rocks; (4) - gabbroids; (5) - norites; (6) - quartzites, $\mathrm{BIF}$, calcareous-silicate rocks.]

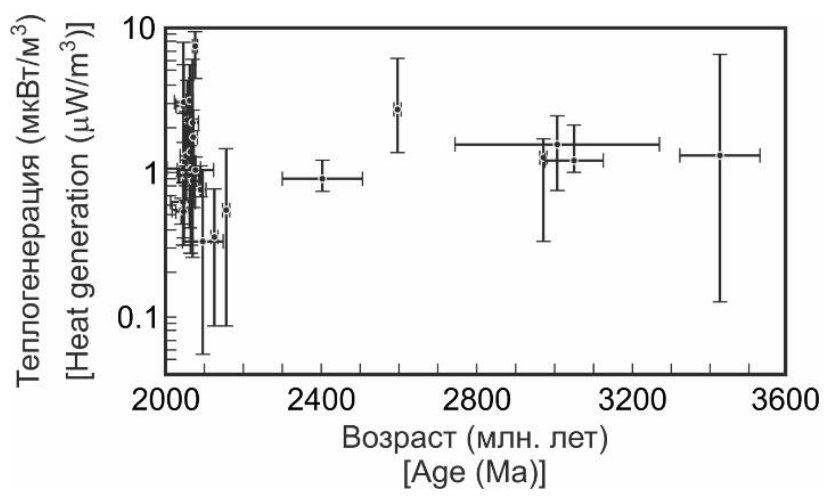

Рис. 7. Зависимость теплогенерации пород фундамента ВКМ от их возраста (показаны диапазоны изменений параметров). [Fig. 7. Dependence of heat generation of VKM basement rocks on their age (ranges of changes in parameters are shown).]

теплогенерацией пород, показанную на рис. 7. Очевидно, что для пород докембрийского фундамента ВКМ не выявляется какой-либо связи между этими параметрами, что говорит о многостадийной эволюции литосферы региона [98] и отсутствии единого «мантийного корня» $[99,100]$, являющегося источником материала формирования верхней коры мегаблока Сарматии.

\section{Заключение}

По результатам обобщения валовых анализов содержаний теплогенерирующих элементов, полученных методом ICP-MS, дана оценка теплогенерации 
пород фундамента центральной части ВЕК. Новые материалы существенно увеличивают объём информации о теплогенерации пород центральной части ВЕК, по сравнению с мировой базой данных IHFC-2021. Для территории ВКМ теплогенерация пород фундамента варьируют в диапазоне от 0.1 до 7.54 мкВт/м ${ }^{3}$, со средним значением 0.528 мкВт/м ${ }^{3}$, что отличается от усреднённой оценки по верхней части континентальной

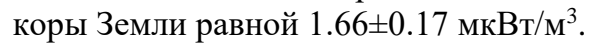

Анализ полученных данных о теплогенерации пород показал отсутствие корреляции между плотностью пород фундамента ВКМ и рассчитанными величинами их теплогенерации. Наряду с этим, выявлена устойчивая связь содержания кремнезёма с величиной рассчитанной теплогенерации пород фундамента ВКМ, что позволяет достаточно просто переходить от химического состава породы к её теплотворной способности. Для главных групп пород докембрийского фундамента ВКМ различающихся по основности, отмечена тенденция связи теплогенерации с составом пород, и отсутствие связи с возрастом формирования пород.

В целом выявленные связи между параметрами комплексов пород и их теплогенерацией можно использовать для формирования начального приближения термической модели верхней коры, что особенно важно в условиях платформы, где латеральная дифференциация пород по их физико-химическим свойствам, весьма высока.

Конфликт интересов: Авторы декларируют отсутствие явных и потенциальных конфликтов интересов, связанных с публикацией настоящей статьи.

Благодарности: Авторы выражают благодарность К. А. Савко за предоставленные первичные данные содержаний редких и рассеянных элементов для ряда пород территории ВКМ, полученные методом ICP-MS, a также за полезные замечания, способствовавшие улучшению содержания статьи.

\section{ЛИТЕРАТУРА}

1. Страхов В. Н. О подходе к решению обратных задач гравиметрии, основанном на теории эквивалентных перераспределений масс // Доклады АН СССР. 1977. Т. 236. № 3. С. 571574.

2. Страхов В. Н. О решении линейных обратных задач гравиметрии и магнитометрии // Доклады АН СССР. 1990. Т. 311. № 6. С. $1348-1352$.

3. Страхов В. Н., Романюк Т. В. Восстановление плотности земной коры и верхней мантии по данным ГСЗ и гравиметрии // Изв. АН СССР, сер. Физика Земли. 1984. № 6. С. 44-63. 4. Голиздра Г. Я. Комплексная интерпретация геофизических полей при изучении глубинного строения земной коры. М.: Недра. 1988. 212 с.

5. Буянов А. Ф., Глазнев В. Н., Р Раевский А. Б., Скопенко Г. Б. Комплексная интерпретация данных гравиметрии, сейсмометрии и геотермии // Геофизический журнал. 1989. T. 11. № 2. C. 30-39.

6. Glaznev V. N., Raevsky A. B., Skopenko G. B. A three-dimensional integrated density and thermal model of the Fennoscandian lithosphere // Tectonophysics. 1996. V. 258. № 1-4. P. 15-33. DOI: https://doi.org/10.1016/0040-1951(95)00147-6

7. Глазнев В. Н. Комплексные геофизические модели лито- сферы Фенноскандии. Апатиты: «КаэМ». 2003. 252 с.

8. Muravina O. M., Glaznev V. N., Zhavoronkin V. I., Mints M. V. Reflection of the Petrophysical Basement Rocks Models in Geophysical Fields. Springer Proceedings in Earth and Environmental Sciences: Practical and Theoretical Aspects of Geological Interpretation of Gravitational, Magnetic and Electric Fields. Eds. D. Nurgaliev, N. Khairullina. Springer Nature Switzerland AG, 2019. P. 49-54.

9. Муравина О. М. Плотностная модель земной коры Воронежского кристаллического массива // Вестник Воронежского государственного университета. Серия: Геология. 2016. № 1. C. 108-114.

10. Чекунов А. В., Старостенко В. И., Красовский С. С., Кутас Р. И., Оровецкий Ю. П., Пашкевич И. К., Трипольский А. А., Елисеева С. В., Куприенко П. Я., Митрофанов Ф. П., Шаров Н. В., Загородный В. Г., Глазнев В. Н., Гарецкий Р. Г., Каратаев Г. И., Аксаментова Н. В., Гутерх А., Грабовска Т., Кобланьски А., Рыка В., Дадлез Р., Цвойдзински С., Корхонен Х., Луосто У., Гаал Г., Журавлев В. А., Садов А.С. Геотрансект Евро-3 // Геофизический журнал. 1993. Т. 15. № 2. С. 3-32.

11. Mitrofanov F. P., Sharov N. V., Zagorodny V. G., Glaznev V N., Korja A. Crustal structure of the Baltic shield along the Pechenga - Kostomuksha - Lovisa geotraverse // International Geology Review. 1998. V. 40. N 11. P. 990-997. DOI: https://doi.org/10.1080/0020681980946

12. Glaznev V. N., Mints M. V., Muravina O. M., Raevsky A. B., Osipenko L. G. Complex geological-geophysical 3D model of the crust in the southeastern Fennoscandian Shield: Nature of density layering of the crust and crust-mantle boundary // Geodynamics \& Tectonophysics. 2015. V. 6. № 2. P. 133-170. DOI: https://doi.org/10.5800/GT-2015-6-2-0176

13. Глазнев В. Н., Минц М. В., Муравина О. М. Плотностное моделирование земной коры центральной части ВосточноЕвропейской платформы // Вестник КРАУНЦ. Сер.: Науки о Земле. 2016. № 1 (29). С. 53-63.

14. Минц М. В., Глазнев В. Н., Муравина О. М. Глубинное строение коры юго-востока Воронежского кристаллического массива по геофизическим данным: геодинамическая эволюция в палеопротерозое и современное состояние коры // Вестник Воронежского государственного университета. Серия: Геология. 2017. № 4. С. 5-23.

15. Mints M. V., Glaznev V. N., Muravina O. M., Sokolova E. Yu. 3D model of Svecofennian Accretionary Orogen and Karelia Craton based on geology, reflection seismics, magnetotellurics and density modelling: Geodynamic speculations // Geoscience Frontiers. 2020. V. 11. № 3. P. 999-1023. DOI: https://doi.org/.1016/j.gsf.2019.10.003

16. Глазнев В. Н., Кукконен И. Т., Раевский А. Б., Ёкинен Я. Новые данные о тепловом потоке в центральной части Кольского полуострова // Доклады РАН. 2004. Т. 396. № 1. С. 102 104.

17. Fuchs S., Norden B., International Heat Flow Commission. The Global Heat Flow Database : Release 2021. GFZ Data Services. DOI: 10.5880/fidgeo.2021.01

18. Fuchs S., Beardsmore G., Chiozzi P., Espinoza-Ojeda O.M., Gola G., Gosnold W., Harris R., Jennings S., Liu S., Negrete-Aranda R., Neumann F., Norden Ben., Poort J., Rajver D., Ray L., Richards M., Smith J., Tanaka A., Verdoya M. A new database structure for the IHFC Global Heat Flow Database. // International Journal of Terrestrial Heat Flow and Applied Geothermics. $2021 . \quad 4(1) . \quad 14 \mathrm{p} . \quad$ DOI: https://doi.org/10.31214/ijthfa.v4i1.62

19. Bogdanova S. V., Bingen B., Gorbatschev R., Kheraskova T. N., Kozlov V. I., Puchkov V. N., Volozh Y. A. The East European Craton (Baltica) before and during the assembly of Rodinia 
// Precambrian Research. 2008. V. 160. N 1-2. P. 23-45. DOI: https://doi.org/10.1016/j.precamres.2007.04.024

20. Mints M. V., Dokukina K. A., Konilov A. N., Philippova I. B., Zlobin V. L., Babayants P. S., Belousova E. A., Blokh Yu. I., Bogina M. M., Bush W. A., Dokukin P. A., Kaulina T. V., Natapov L. M., Piip V. B., Stupak V. M., Suleimanov A. K., Trusov A. A., Van K. V., Zamozhniaya N. G. East European Craton: Early Precambrian history and 3D models of deep crustal structure // Geol. Soc. of Amer., Special Paper. 2015. V. 510. 433 p.

21. Artemieva I. M. Global $1^{\circ} \times 1^{\circ}$ thermal model TC1 for the continental lithosphere: Implications for lithosphere secular evolution // Tectonophysics. 2006. V.416. P. 245-277. DOI: https://doi.org/10.1016/j.tecto.2005.11.022

22. Муравина О. М. Методология построения комплексных моделей литосферы платформенных областей в условиях неполноты информации: автореферат дис. ... д-ра техн. наук. М.: Ин-т физики Земли им. О.Ю. Шмидта РАН, Воронеж, 2016. $49 \mathrm{c}$.

23. Rybach L. Determination of the heat production rate / In: Haenel R., Rybach L., Stegena, L. (Eds.). Handbook of Terrestrial Heat-Flow Density Determination. Kluwer Academic Publishers. Dordrecht. 1988. P. 125-142. DOI https://doi.org/10.1007/978-94-009-2847-3

24. Ruedas T. Radioactive heat production of six geologically important nuclides // Geochemistry, Geophysics, Geosystems. 2017. V. $18 . \quad$ N 9. P. 3530-3541. DOI: https://doi.org/10.1002/2017GC006997.

25. Chiozzi P., De Felice P., Faziob A., Pasquale V., Verdoya M. Laboratory application of $\mathrm{NaI}(\mathrm{Tl}) \gamma$-ray spectrometry to studies of natural radioactivity in geophysics // Applied Radiation and Isotopes. 2000. V. 53. P. 127-132.

26. Goes S., Hasterok D., Schutt D., Klöcking M. Continental lithospheric temperatures: A review // Physics of the Earth and Planetary Interiors. 2020. V. $306.106509 . \quad$ DOI: https://doi.org/10.1016/j.pepi.2020.10650

27. Тейлор С. Р., Мак-Леннан С. М. Континентальная кора: её состав и эволюция. М.: Мир. 1988. 384 с.

28. McDonough W. F., Sun S.-s. Chemical and isotopic systematics of oceanic basalts: implications for mantle composition and processes // Geological Society, London, Special Publications. $1989 . \quad$ V. $42 . \quad$ P. 313-345. https://doi.org/10.1144/GSL.SP.1989.042.01.19

29. McDonough W. F., Sun S.-s. The composition of the Earth // Chemical Geology. 1995. V. 120. P. 223-253. DOI: https://doi.org/10.1016/0009-2541(94)00140-4

30. Молотков С. П., Костюков В. И., Лосицкий В. И. Кривцов И. И., Золототрубова Э. И., Пономарёва Р. Н. Геологическая карта Воронежского кристаллического массива масштаба 1 : 500 000. МПР РФ, ГПП «Воронежгеология», ОАО «Белгородгеология», ВГУ, НКПР «Хорс». Воронеж. 1999.

31. Терентьев Р. А., Савко К. А., Скрябин В. Ю., Кориш Е. Х. Петротип палеопротерозойского тоналит-трондьемит-гранодиоритового усманского комплекса Лосевской структурно-формационной зоны (Воронежский кристаллический массив) // Вестник Воронежского государственного университета. Серия: Геология. 2015. № 4. С. 42-60.

32. Щипанский А. А., Самсонов А. В., Петрова А. Ю., Ларионова Ю. О. Геодинамика восточной окраины Сарматии в палеопротерозое // Геотектоника. 2007. № 1. С. 43-70.

33. Терентьев Р. А. Проявление син- и постколлизионных гранитов Лосевской шовной зоны (Воронежский кристаллический массив) // Вестник Воронежского государственного университета. Серия: Геология. 2013. № 2. С. 70-85.

34. Terentiev R. A., Savko K. A., Santosh M., Korish E. H., Sarkisyan L. S. Paleoproterozoic granitoids of the Losevo terrane,
East European Craton: Age, magma source and tectonic implications // Precambrian Research. 2016. V. 287. P. 48-72. DOI: https://doi.org/10.1016/j.precamres.2016.10.015

35. Терентьев Р. А., Савко К. А. Минеральная термобарометрия и геохимия палеопротерозойских магнезиально-калиевых гранитоидов павловского плутона, Восточно-Европейский кратон // Вестник Воронежского государственного университета. Серия: Геология. 2017. № 3. С. 34-45.

36. Terentiev R. A., Savko K. A., Petrakova M. E., Santosh M., Korish E. H. Paleoproterozoic granitoids of the Don terrane, EastSarmatian Orogen: age, magma source and tectonic implications // Precambrian Research. 2020. V. 346. № 105790. DOI: https://doi.org/10.1016/j.precamres.2020.10579

37. Савко К. А., Самсонов А. В., Базиков Н. С., Ларионова Ю. О., Хиллер В. В., Вотяков С. Л., Скрябин В. Ю., Козлова Е. Н. Гранитоиды востока Воронежского кристаллического массива: геохимия, Th-U-Pb возраст и петрогенезис // Becmник Воронежского государственного университета. Серия: Геология. 2011. № 2. С. 98-115.

38. Савко К. А., Самсонов А. В., Ларионов А. Н., Ларионова Ю. О., Базиков Н. С. Палеопротерозойские граниты А- и Sтипов востока Воронежского кристаллического массива: геохронология, петрогенезис и тектоническая обстановка формирования // Петрология. 2014. Т. 22. № 3. C. 235-264. DOI: https://doi.org/10.7868/S0869590314030054

39. Савко К. А., Терентьев Р. А. Геохронология кварцевых диоритов романовского плутона Воронежского кристаллического массива // Вестник Воронежского государственного университета. Серия: Геология. 2017. № 2. С. 74-80.

40. Terentiev R. A., Savko K. A., Santosh M. Paleoproterozoic crustal evolution in the East Sarmatian Orogen: Petrology, geochemistry, $\mathrm{Sr}-\mathrm{Nd}$ isotopes and zircon U-Pb geochronology of andesites from the Voronezh massif, Western Russia // Lithos. 2016. $246-247$
P. 61-80.
DOI:

V.

https://doi.org/.1016/j.lithos.2015.12.025

41. Терентьев Р. А., Савко К. А., Стрик Ю. Н. Палеопротерозойские андезиты восточной части Воронежского кристаллического массива (Восточно-Сарматский ороген): геохимия и петрогенезис // Вестник Воронежского государственного университета. Серия: Геология. 2016. № 1 С. 66-75.

42. Савко К. А., Самсонов А. В., Базиков Н. С. Метатерригенные породы воронцовской серии Воронежского кристаллического массива: геохимия, особенности формирования и источники сноса // Вестник Воронежского государственного университета. Серия: Геология. 2011. № 1. С. 70-94.

43. Терентьев Р. А., Савко К. А., Базиков Н. С. Геохимия и условия кристаллизации пород габбродиорит-анортозитового и монцогранитного интрузивов лосевской структурноформационной зоны (Воронежский кристаллический массив) // Вестник Воронежского государственного университета. Серия: Геология. 2014. № 4. С. 37-52.

44. Terentiev R. A., Savko K. A., Santosh M. Post-collisional two-stage magmatism in the East Sarmatian Orogen, East European Craton: evidence from the Olkhovsky ring complex // Journal of the Geological Society. 2018. V. 175(1):86. DOI: https://doi.org/10.1144/jgs2017-017

45. Терентьев Р. А., Савко К. А., Базиков Н. С., Пилюгин С. М. Дайки высокоглиноземистых норитов и диоритов в Елань-Коленовском мафит-ультрамафитовом плутоне востока Воронежского кристаллического массива: минералогия, геохимия, условия кристаллизации // Вестник Воронежского государственного университета. Серия: Геология. 2015. № 3. C. 35-49.

46. Терентьев Р. А., Савко К. А. Высокомагнезиальные низкотитанистые габбро-гранитные серии в палеопротерозое Восточной Сарматии: геохимия и условия формирования // 
Геология и геофизика. 2016. Т. 57. № 6. С. 1155-1183. DOI: https://doi.org/10.15372/GiG20160605

47. Терентьев Р. А. Геохимия и стратиграфия пород метатерригенного разреза стрелицкой толщи лосевской серии Воронежского кристаллического массива. Статья II: геохимия // Вестник Воронежского государственного университета. Серия: Геология. 2013. № 1. С. 127-138.

48. Терентьев Р. А. Геохимия и палеогеодинамические реконструкции вулканогенных пород лосевской серии Воронежского кристаллического массива: значение для литологостратиграфического расчленения // Вестник Воронежского государственного университета. Серия: Геология. 2016. № 4. C. 31-43.

49. Terentiev R. A., Savko K. A., Santosh M. Paleoproterozoic evolution of the arc-back-arc system in the east Sarmatian orogen (East European Craton): zircon shrimp geochronology and geochemistry of the Losevo volcanic suite // American Journal of Science. 2017. V. 317. P. 707-753. DOI: https://doi.org/10.2475/06.2017.03

50. Савко К. А., Самсонов А. В., Сальникова Е. Б., Ларионов А. Н., Червяковская М. В., Базиков Н. С., Кориш Е. Х. Геохронология ТТГ ассоциации в мезоархее Курского блока Восточной Сарматии // Вестник Воронежского государственного университета. Серия: Геология. 2019. № 2. С. 70-80.

51. Savko K. A., Samsonov A. V., Larionov A. N., Chervyakovskaya M. V., Korish E. H., Larionova Y. O., Bazikov N. S., Tsybulyaev S. V. A buried Paleoarchean core of the Eastern Sarmatia, Kursk block: U-Pb, $\mathrm{Lu}-\mathrm{Hf}$ and $\mathrm{Sm}-\mathrm{Nd}$ isotope mapping and paleotectonic application // Precambrian Research 2021. V. 353. № 106021. DOI: https://doi.org/10.1016/j.precamres.2020.106021

52. Савко К. А., Самсонов А. В., Базиков Н. С., Козлова Е. Н. Палеопротерозойские гранитоиды тим-ястребовской структуры Воронежского кристаллического массива: геохимия, геохронология и источники расплавов // Вестник Воронежского государственного университета. Серия: Геология. 2014. № 2. C. 56-78.

53. Кориш Е. Х., Савко К. А., Самсонов А. В., Червяковская М. В. Палеопротерозойские диориты Троснянского массива Курского блока Сарматии: U-Pb возраст, изотопная систематика и источники расплавов // Вестник Воронежского государственного университета. Серия: Геология. 2020. № 1. С. 87-99. DOI: https://doi.org/10.17308/geology.2020.1/2517

54. Савко К. А., Кориш Е. Х., Пилюгин С. М., Полякова Т. Н. Фазовые равновесия редкоземельных минералов при метаморфизме углеродистых сланцев тим-ястребовской структуры, Воронежский кристаллический массив // Петрология. 2010. T. 18. № 4. C. 402-433.

55. Кориш Е. Х., Савко К. А. Геохимия высокоуглеродистых сланцев тим-ястребовской структуры (Воронежский кристаллический массив) // Вестник Воронежского государственного университета. Серия: Геология. 2010. № 2. С. $108-116$.

56. Савко К. А., Цыбуляев С. В., Кориш Е. Х. Метабазиты тим-ястребовской и авильской рифтогенных структур на восточной окраине Сарматии: геохимия, источники расплавов и геологические корреляции // Вестник Воронежского государственного университета. Серия: Геология. 2016. № 2. С. 51-65.

57. Цыбуляев С. В., Савко К. А., Самсонов А. В., Кориш Е. Х. Палеопротерозойские рифтогенные вулканиты OIB и MORB-типов Курского блока восточной Сарматии: петрология и геодинамика // Петрология. 2021. Т. 29. № 2. С. 136171. DOI: https://doi.org/10.31857/S0869590321020060

58. Savko K. A., Samsonov A. V., Kholina N. V., Larionov A. N., Zaitseva M. V., Korish E. H., Bazikov N. S., Terentiev
R. A. 2.6 Ga high-Si rhyolites and granites in the Kursk Domain, Eastern Sarmatia: Petrology and application for the Archaean palaeocontinental correlations // Precambrian Research. 2019. V. 322. P. 170-192. DOI: https://doi.org/10.1016/j.precamres.2019.01.006

59. Савко К. А., Самсонов А. В., Сальникова Е. Б., Котов А. Б., Ларионов А. Н., Кориш Е. Х., Ковач В. П., Базикова Н. С. Мезоархейские тоналит-трондьемит-гранодиоритовые ассоциации Восточной Сарматии: возраст и геологическое положение // Стратиграфия. Геологическая корреляция. 2019. T. 27. № 5. C. 4-18. DOI: https://doi.org/31857/S0869$592 \times 2754-18$

60. Цыбуляев С. В., Савко К. А. Геохимическая типизация палеопротерозойских вулканитов бимодальной серии курбакинской свиты Курского блока Восточной Сарматии // Becmник Воронежского государственного университета. Серия: Геология. 2017. № 1. С. 61-75.

61. Савко К. А., Цыбуляев С. В. Палеопротерозойские постколлизионные вулканиты бимодальной серии курбакинской свиты Воронежского кристаллического массива. Граниты $u$ эволюиия Земли: мантия и кора в гранитообразовании. Материалы III международн. геол. конф., 2017, Екатеринбург: ИГГ УрО РАН. 2017. С. 259-261.

62. Савко К. А., Базиков Н. С., Артеменко Г. В. Геохимическая эволюция железисто-кремнистых формаций Воронежского кристаллического массива в раннем докембрии: источники вещества и геохронологические ограничения // Стратиграфия. Геологическая корреляция. 2015. Т. 23. № 5. С. $3-$ 21. DOI: https://doi.org/10.7868/S0869592X15050063

63. Савко К. А., Кузнецов А. Б., Овчинникова М. Ю. Карбонатные отложения Восточной Сарматии (раннедокембрийская игнатеевская свита, Курский блок): условия образования и палеоконтинентальные корреляции // Стратиграфия. Геологическая коррелячия. 2020. Т. 28. № 3. С. 3-26. DOI: https://doi.org/10.31857/S0869592X20030102

64. Савко К. А., Холина Н. В., Самсонов А. В., Кориш Е. Х., Червяковская М. В., Базиков Н. С., Ларионов А. Н. Петротип неоархейского атаманского комплекса гранитов Курского блока Сарматии: геохимия, геохронология, изотопная систематика // Вестник Воронежского государственного университета. Серия: Геология. 2020. № 2. С. 20-43. DOI: https://doi.org/10.17308/geology.2020.2/2857

65. Цыбуляев С. В., Савко К. А., Червяковская М. В. Палеопротерозойские андезитовые порфириты Курского блока Восточной Сарматии: геохимия и источник расплавов // Вестник Воронежского государственного университета. Серия: Геология. 2019. № 1. С. 26-38. DOI: https://doi.org/10.17308/geology.2019.1/1701

66. Цыбуляев С.В., Савко К.А. U-Pb изотопный возраст и тектоническая позиция палеопротерозойских андезитовых порфиритов Курского блока восточной Сарматии // Вестник Воронежского государственного университета. Серия: Гео$\begin{array}{lllll}\text { логия. } 2018 . & \text { № } & 3 . & \text { С. 29-35. }\end{array}$ DOI: https://doi.org/10.17308/geology.2018.3/1559

67. Бибикова Е. В., Богданова С. В., Постников А. В., Попова Л. П., Кирнозова Т. И., Фугзан М. М., Глущенко В. В. Зона сочленения Сарматии и Волго-Уралии: изотопно-геохронологическая характеристика супракрустальных пород и гранитоидов // Стратиграфия. Геологическая корреляиия. 2009. T. 17. № 6. С. 3-16.

68. Bogdanova S., De Waele B., Bibikova E., Belousova E.A., Postnikov A.V., Fedotova A.A., Popova L.P. Volgo-Uralia: the first $\mathrm{U}-\mathrm{Pb}, \mathrm{Lu}-\mathrm{Hf}$ and $\mathrm{Sm}-\mathrm{Nd}$ isotopic evidence of preserved Paleoarchean crust // American Journal of Science. 2010. V. 310. P. 1345-1383. DOI: https://doi.org/10.2475/10.2010.06 
69. Бибикова Е. В., Богданова С. В., Постников А. В., Федотова А. А., Клаэссон С., Кирнозова Т. И., Фугзан М. М., Попова Л. П. Ранняя кора Волго-Уральского сегмента Восточно-Европейского кратона: изотопно-геохронологическое изучение терригенного циркона из метаосадочных пород большечеремшанской серии и их $\mathrm{Sm}-\mathrm{Nd}$ модельный возраст // Стратиграфия. Геологическая корреляция. 2015. Т. 23. № $1 . \quad$ C. $3 . \quad 3$ DOI: https://doi.org/10.7868/S0869592X15010032

70. Bogdanova S. V., Belousova E., Waele B. D., Larionov A. N., Piazolo S., Postnikov A. V., Samsonov A. V. Palaeoproterozoic reworking of early Archaean lithospheric blocks: Rocks and zircon records from charnockitoids in Volgo-Uralia // Precambrian Research. V. 360. 2021. N 106224. DOI: https://doi.org/10.1016/j.precamres.2021.106224

71. Носова А. А., Возняк А. А., Богданова С. В., Савко К. А., Лебедева Н. М., Травин А. В., Юдин Д. С., Пейдж Л., Ларионов А. Н., Постников А. В. Раннекембрийский сиенитовый и монцонитовый магматизм на юго-востоке Восточно-Европейской платформы: петрогенезис и тектоническая обстановка формирования // Петрология. 2019. Т. 27. № 4. С. 357 400. DOI: https://doi.org/10.31857/S0869-5903274357-400

72. Бибикова Е. В., Лобач-Жученко С. Б., Артеменко Г. В., Клаэссон С., Коваленко А. В., Крылов И. Н. Позднеархейские магматические комплексы Приазовского террейна Украинского щита: геологическое положение, изотопный возраст, источники вещества // Петрология. 2008. Т. 16. № 3. С. $227-247$.

73. Артеменко Г. В., Лобач-Жученко С. Б., Бибикова Е. В. Геология, возраст и состав архейских горнблендитов западного Приазовья // Геологический журнал. 2008. № 2. С. 35-43. 74. Митрохин А. В., Богданова С. В., Шумлянский Л. В. Полибарическая кристаллизация анортозитов Коростенского плутона (Украинский щит) // Мінералогічний журнал. 2008. T. 30. № 2 (156). С. 36-56.

75. Шумлянский Л. В., Богданова С. В. U-PB возраст цирконов и геохимические особенности риолитов Овручской впадины, северо-западный район Украинского щита // Мінералогічний журнал. 2009. Т. 31. № 1 (159). С. 40-49.

76. Митрохин А. В., Богданова С. В., Билан Е. В. Петрология Малинского массива рапакиви (Коростенский плутон) // Мінералогічний журнал. 2009. Т. 31. № 2 (160). С. 66-82.

77. Бибикова Е. В., Клаэссен С., Федотова А. А., Артеменко Г. В., Ильинский Л. С. Терригенный циркон архейских зеленокаменных поясов - источник информации о ранней коре Земли: Приазовье и Приднепровье, Украинский щит // Геохимия. 2010. № 9. С. 899-916.

78. Бибикова Е. В., Федотова А. А., Клаэссен С., Артеменко Г. В., Аносова М. О. Ранняя кора Приазовского домена Украинского щита: изотопно-геохронологическое и геохимическое изучение терригенных цирконов метаосадочных пород Федоровской структуры // Стратиграфия. геологическая корреляция. 2012. Т. 20. № 2. С. 13-26.

79. Бибикова Е. В., Клаэссон С., Федотова А. А., Степанюк Л. М., Шумлянский Л. В., Кирнозова Т. И., Фугзан М. М., Ильинский Л.С. Изотопно-геохронологическое (U-Th-Pb, $\mathrm{Lu}-\mathrm{Hf})$ изучение цирконов архейских магматических и метаосадочных пород Подольского домена Украинского щита // Геохимия. 2013. № 2. С. 99-121. DOI: https://doi.org/10.7868/S0016752513020039

80. Bogdanova S. V., Gintov O. B., Kurlovich D. M., Lubnina N. V., Mimmi K. M. Nilsson, Orlyuk M. I., Pashkevich I. K., Shumlyanskyy L. V., Starostenko V. I. Late Palaeoproterozoic mafic dyking in the Ukrainian Shield of Volgo-Sarmatia caused by rotation during the assembly of supercontinent Columbia
(Nuna) // Lithos. 2013. V. 174. P. 196-216. DOI: https://doi.org/10.1016/j.lithos.2012.11.002

81. Шумлянский Л. В., Митрохин А. В., Дюшен Ж-К., Богданова С. В., Биллстрём Ш., Омельченко А. Н., Багински Б. Петрология даек субщелочных долеритов Коростенского комплекса, северо-западный район Украинского щита // Мінералогічний журнал. 2018. Т. 40. № 1 (195). С. 32-52. DOI: https://doi.org/10.15407/mineraljournal.40.01.032

82. Shumlyanskyy L., Wilde S. A., Nemchin A. A., Claesson S., Billstrom K., Baginski B. Eoarcean rock association in the Dniester-Bouh domain of the Ukrainian shield: a suite of LILEdepleted enderbites and mafic granulites // Precambrian Research. 2021. V. 352. 106101. DOI: https://doi.org/j.precamres.2020.106101

83. Vejelytea I., Bogdanova S., Skridlaited G. Early Mesoproterozoic magmatism in northwestern Lithuania: A new $\mathrm{U}-\mathrm{Pb}$ zircon dating // Estonian Journal of Earth Sciences. 2015. V. 64(3). P. 189-198. DOI: https://doi.org/10.3176/earth.2015.26

84. Глазнев В. Н., Муравина О. М., Жаворонкин В. И., Лебедев И.П., Воронова Т. А. Петроплотностная карта докембрийского фундамента Воронежского кристаллического массива. Масштаб 1:1000 000. Объяснительная записка. Воронеж. Изд-во «Научная книга». 2020. 101 с.

85. Красовский С. С. Отражение динамики земной коры континентального типа в гравитационном поле. Киев: Наукова думка, 1981.264 с.

86. Литосфера Центральной и Восточной Европы: ВосточноЕвропейская платформа. Ред.: В.Б. Соллогуб. Киев: Наукова думка. 1989. 188 с

87. Galitchanina L. D., Glaznev V. N., Mitrofanov F. P., Olesen O., Henkel H. Surface density characteristics of the Baltic Shield and adjacent territories. Norges Geologiske Undersøkelse. Special Publication «Geology of the Eastern Finnmark - Western Kola Peninsula Region». Proceedings of the 1st. International Barents Symposium «Geology and Minerals in the Barents Region». Eds. D. Roberts, Ø.Nordgulen. 1995. P. 349-354.

88. Физические свойства осадочных пород Восточно-Европейской платформы. Ред.: Н.В. Подоба, М.Л. Озерская. М.: Недра. 1975. 280 с.

89. Саркисова Н. П. Государственная геологическая карта Российской Федерации. М-37, 38 (Воронеж). Масштаб 1: 1000000. М.: МПР РФ. 2001.

90. Глазнев В. Н., Муравина О. М., Воронова Т. А., Холин В. М. Оценка мощности гравиактивного слоя земной коры Воронежского кристаллического массива // Вестник Воронежского государственного университета. Серия: Геология. 2014. № 4. C.78-84.

91. Rudnick R. L., Gao S. Composition of the Continental Crust / In: Treatise on Geochemistry (Second Edition). Eds.: R.L. Rudnick. Elsevier. 2014. V. 4. P. 1-51. DOI: https://doi.org/10.1016/B978-0-08-095975-7.00301-6

92. Artemieva I. M., Thybo H., Jakobsen K., Sorensen N. K., Nielsen L.S.K. Heat production in granitic rocks: Global analysis based on a new data compilation GRANITE2017 // Earth-Science Review. 2017. $\quad$ V. $172 . \quad$ P. 1-26. $\quad$ DOI: https://doi.org/10.1016/j.earscirev.2017.07.003

93. Vila M., Fernandez M., Jiménez-Munt I. Radiogenic heat production variability of some common lithological groups and its significance to lithospheric thermal modeling // Tectonophys$\begin{array}{llll}\text { ics. } & 2010 . & \text { V. 490(3-4). } & \text { P. 152-164. }\end{array}$ https://doi.org/10.1016/j.tecto.2010.05.003

94. Hasterok D., Webb J. On the radiogenic heat production of igneous rocks // Geoscience Frontiers. 2017. V. 8(5). P. 919-940. DOI: https://doi.org/10.1016/j.gsf.2017.03.006 
95. Муравина О. М. Метод группового учёта аргументов при анализе геофизических данных // Геофизика. 2012. № 6. С. 16-20.

96. Gard M., Hasterok D., Hand M., Cox G. Variations in continental heat production from $4 \mathrm{Ga}$ to the present: Evidence from geochemical data // Lithos. 2019. Vol. 342-343. P. 391-406. DOI: https://doi.org/10.1016/j.lithos.2019.05.034

97. Hasterok D., Gard M., Cox G., Hand M. A 4 Ga record of granitic heat production: implications for geodynamic evolution and composition of the early Earth // Precambrian Research. $2019 . \quad 331$. https://doi.org/10.1016/j.precamres.2019.105375
98. Савко К.А., Самсонов А.В., Холин В.М. Базиков Н.С. Мегаблок Сарматия как осколок суперкратона Ваалбара: корреляция геологических событий на границе архея и палеопротерозоя // Стратиграфия. Геологическая корреляиия. 2017. $\begin{array}{llllll}\text { T. } 25 . & \text { № } & 2 . & \text { C. } & 3-26 . & \text { DOI: }\end{array}$ https://doi.org/10.7868/S0869592X17020065

99. Балашов Ю. А., Глазнев В. Н. Влияние плюмового магматизма на динамику докембрийского корообразования // Доклады РАН. 2004. Т. 395. № 1. С. 78-81.

100. Арзамасцев А. А., Глазнев В. Н. Плюм-литосферное взаимодействие в условиях древнего сублитосферного мантийного киля на примере Кольской щелочной провинции // Доклады РАН. 2008. Т. 419. № 4. С. 515-518.

\title{
GEOPHYSICS
}

UDC 550.361.2

DOI: https://doi.org/10.17308/geology.2021.3/3651

ISSN 1609-0691

Received: 30.07.2021

Accepted: 02.09.2021

Published online: 07.10.2021

\section{Heat generation of basement rocks in the central part of the East European Craton}

\author{
(C) 2021 V. N. Glaznev ${ }^{凶 1,2}$, O. M. Muravina ${ }^{1}$, M. V. Mints $^{3}$, D. M. Chernyshova ${ }^{1}$ \\ ${ }^{1}$ Voronezh State University, 1 Universitetskaya pl., Voronezh 394018, Russian Federation \\ ${ }^{2}$ Geological Institute of the Kola Science Centre of the Russian Academy of Sciences, \\ 14 Fersmana ul., Apatity 184209, Russian Federation \\ ${ }^{3}$ Geological Institute RAS, Pyzhevsky per., 7, bld. 1, Moscow 119017, Russian Federation
}

\begin{abstract}
Introduction: We considered the general principles of creating complex geophysical models for the lithosphere of the central part of the East European Craton and the role of geothermal models in such models. In order to form a reliable initial estimate for a thermal model of the upper crust, we generalised the data on the content of heat generation elements in the rocks of the Early Cambrian basement.

Initial data: We studied the peculiar features of the total content of rare and scattered elements obtained using the method of inductively coupled plasma atomic mass spectrometry in the samples of typical rocks of the studied region. A consolidated database was compiled for the content of heat generation elements (potassium, thorium, uranium) and the total content of silica in typical rocks of the crystalline basement of the craton. Assessment of heat generation of the basement rocks: We calculated the heat generation of the crystalline basement rocks in the area based on the initial data on the concentration of radiogenic elements. To assess the values of heat generation, we used the data on the density of the rocks of the basement of the East European Craton and its individual parts. The obtained results of the assessment of heat generation characterise the upper inhomogeneous part of the basement extending to the lower border of the region's graviactive layer.

Data analysis and discussion: We obtained the value of heat generation of the Early Cambrian basement rocks that varies from 0.1 to $7.54 \mu \mathrm{W} / \mathrm{m}^{3}$ with the average value of $0.528 \mu \mathrm{W} / \mathrm{m}^{3}$. Data analysis showed that there was no correlation between the density of the region's basement rocks and the calculated values of their heat
\end{abstract}

The content is available under Creative Commons Attribution 4.0 License.

\footnotetext{
$\bowtie$ Victor N. Glaznev, e-mail: glaznev@geol.vsu.ru
} 
generation. A stable connection was found between the content of silica $\left(\mathrm{SiO}_{2}\right)$ and the value of the calculated heat generation of the rocks. As for the main groups of the basement rocks, heat generation tends to be related to the composition of the rocks, but there is no connection to the age of the formation of the rocks.

Conclusions: We presented the main results of the conducted research and outlined a plan for the formation of an initial estimate for the heat generation of the upper crust in the thermal model of the region's lithosphere. Keywords: East European Craton, Precambrian basement, heat generation of rocks.

Funding: grants No. 19-05-00336 and No. 20-05-00190 supported by Russian Foundation for Basic Research.

For citation: Glaznev V. N., Muravina O. M., Mints M. V., Chernyshova D. M. Heat generation of basement rocks in the central part of the East European Craton. Vestnik Voronezhskogo gosudarstvennogo universiteta. Seriya: Geologiya - Proceedings of Voronezh State University. Series: Geology, 2021, no. 3, pp. 60-78. DOI: https://doi.org/10.17308/geology.2021.3/3651

Conflict of interests: The authors declare the absence of obvious and potential conflicts of interest related to the publication of this article.

Acknowledgments: The authors are grateful to K. A. Savko for providing the primary data on the contents of trace and trace elements for a number of rocks of the VKM territory, obtained by the ICP-MS method and for useful comments to improve the content of the article.

\section{REFERENCES}

1. Strakhov V. N. O podkhode k resheniyu obratnykh zadach gravimetrii, osnovannom na teorii ekvivalentnykh pereraspredelenii mass [On an approach to solving inverse problems of gravimetry based on the theory of equivalent redistribution of masses]. Doklady AN SSSR - Reports of the USSR Academy of Sciences, 1977, vol. 236, no. 3, pp. 571-574. (In Russ.)

2. Strakhov V. N. O reshenii lineinykh obratnykh zadach gravimetrii i magnitometrii [On the solution of linear inverse problems of gravimetry and magnetometry]. Doklady AN SSSR - Reports of the USSR Academy of Sciences, 1990, vol. 311, no. 6, pp. 1348-1352. (In Russ.)

3. Strakhov V. N., Romanyuk T. V. Vosstanovlenie plotnosti zemnoi kory i verkhnei mantii po dannym GSZ i gravimetrii $[R e-$ construction of the density of the earth's crust and upper mantle from DSS and gravimetry data]. Izv. AN SSSR, ser. Fizika Zemli - Izvestia of the USSR Academy of Sciences, ser. Physics of the Earth, 1984, no. 6, pp. 44-63. (In Russ.)

4. Golizdra G. Ya. Kompleksnaya interpretatsiya geofizicheskikh polei pri izuchenii glubinnogo stroeniya zemnoi kory [Complex interpretation of geophysical fields in the study of the deep structure of the earth's crust]. Moscow, Nedra publ., 1988, 212 p. (In Russ.)

5. Buyanov A. F., Glaznev V. N., Raevskii A. B., Skopenko G. B. Kompleksnaya interpretatsiya dannykh gravimetrii, seismometrii i geotermii [Complex interpretation of gravimetry, seismometry and geothermal data]. Geofizicheskii zhurnal - Geophysical journal, 1989, vol. 11, no. 2, pp. 30-39. (In Russ.)

6. Glaznev V. N., Raevsky A. B., Skopenko G. B. A three-dimensional integrated density and thermal model of the Fennoscandian lithosphere. Tectonophysics, 1996, vol. 258, no. 1-4, pp. 15-33. DOI: https://doi.org/10.1016/0040-1951(95)00147-6 7. Glaznev V. N. Kompleksnye geofizicheskie modeli litosfery Fennoskandii [Complex geophysical models of the lithosphere of Fennoscandia]. Apatity, «KaeM» publ., 2003, 252 p. (In Russ.) 8. Muravina O. M., Glaznev V. N., Zhavoronkin V. I., Mints M. V. Reflection of the Petrophysical Basement Rocks Models in Geophysical Fields. Springer Proceedings in Earth and Environmental Sciences: Practical and Theoretical Aspects of Geological Interpretation of Gravitational, Magnetic and Electric Fields. Eds. D. Nurgaliev, N. Khairullina. Springer Nature Switzerland AG, 2019, pp. 49-54.

9. Muravina O. M. Plotnostnaya model' zemnoi kory Voronezhskogo kristallicheskogo massiva. Vestnik Voronezhskogo gosudarstvennogo universiteta. Seriya: Geologiya - Proceedings of Voronezh State University. Series: Geology, 2016, no. 1, pp. 108-114. (In Russ.)

10. Chekunov A. V., Starostenko V. I., Krasovskii S. S., Kutas R. I., Orovetskii Yu. P., Pashkevich I. K., Tripol'skii A. A., Eliseeva S. V., Kuprienko P. Ya., Mitrofanov F. P., Sharov N. V., Zagorodnyi V. G., Glaznev V. N., Garetskii R. G., Karataev G. I., Aksamentova N. V., Guterkh A., Grabovska T., Koblan'ski A., Ryka V., Dadlez R., Tsvoidzinski S., Korkhonen Kh., Luosto U., Gaal G., Zhuravlev V. A., Sadov A.S. Geotransekt Evro-3 [Geotranssect Euro-3]. Geofizicheskii zhurnal - Geophysical journal, 1993, vol. 15, no. 2, pp. 3-32. (In Russ.)

11. Mitrofanov F. P., Sharov N. V., Zagorodny V. G., Glaznev V N., Korja A. Crustal structure of the Baltic shield along the Pechenga - Kostomuksha - Lovisa geotraverse. International Geology Review, 1998, vol. 40, no. 11, pp. 990-997. DOI: https://doi.org/10.1080/0020681980946

12. Glaznev V. N., Mints M. V., Muravina O. M., Raevsky A. B., Osipenko L. G. Complex geological-geophysical 3D model of the crust in the southeastern Fennoscandian Shield: Nature of density layering of the crust and crust-mantle boundary. Geodynamics \& Tectonophysics, 2015, vol. 6, no. 2, pp. 133-170. DOI: https://doi.org/10.5800/GT-2015-6-2-0176

13. Glaznev V. N., Mints M. V., Muravina O. M. Plotnostnoe modelirovanie zemnoi kory tsentral'noi chasti Vostochno-Evropeiskoi platformy [Density modeling of the earth's crust in the central part of the East European platform]. Vestnik KRAUNTs. Nauki o Zemle, 2016, no. 1 (29), pp. 53-63. (In Russ.)

14. Mints M. V., Glaznev V. N., Muravina O. M. Deep structure of the crust of the southeast of the Voronezh crystalline massif according to geophysical data: geodynamic evolution in the Paleoproterozoic and the current state of the crust. Vestnik Voronezhskogo gosudarstvennogo universiteta. Seriya: Geologiya Proceedings of Voronezh State University. Series: Geology, 2017, no. 4, pp. 5-23. (In Russ.)

15. Mints M. V., Glaznev V. N., Muravina O. M., Sokolova E. Yu. 3D model of Svecofennian Accretionary Orogen and Karelia Craton based on geology, reflection seismics, magnetotellurics and density modelling: Geodynamic speculations. Geoscience Frontiers, 2020, vol. 11, no. 3, pp. 999-1023. DOI: https://doi.org/10.1016/j.gsf.2019.10.003

16. Glaznev V. N., Kukkonen I. T., Raevskii A. B., Ekinen Ya. Novye dannye o teplovom potoke $\mathrm{v}$ tsentral'noi chasti Kol'skogo 
poluostrova [New data on the heat flow in the central part of the Kola Peninsula]. Doklady RAN-RAS reports, 2004, vol. 396, no. 1, pp. 102-104. (In Russ.)

17. Fuchs S., Norden B., International Heat Flow Commission. The Global Heat Flow Database : Release 2021. GFZ Data Services. DOI: 10.5880/fidgeo.2021.01

18. Fuchs S., Beardsmore G., Chiozzi P., Espinoza-Ojeda O.M., Gola G., Gosnold W., Harris R., Jennings S., Liu S., Negrete-Aranda R., Neumann F., Norden Ben., Poort J., Rajver D., Ray L., Richards M., Smith J., Tanaka A., Verdoya M. A new database structure for the IHFC Global Heat Flow Database. International Journal of Terrestrial Heat Flow and Applied Geothermics, 2021, 4 (1), 14 p. DOI: https://doi.org/10.31214/ijthfa.v4i1.62

19. Bogdanova S. V., Bingen B., Gorbatschev R., Kheraskova T. N., Kozlov V. I., Puchkov V. N., Volozh Y. A. The East European Craton (Baltica) before and during the assembly of Rodinia. Precambrian Research, 2008, vol. 160, no. 1-2, pp. 23-45. DOI: https://doi.org/10.1016/j.precamres.2007.04.024

20. Mints M. V., Dokukina K. A., Konilov A. N., Philippova I. B., Zlobin V. L., Babayants P. S., Belousova E. A., Blokh Yu. I., Bogina M. M., Bush W. A., Dokukin P. A., Kaulina T. V., Natapov L. M., Piip V. B., Stupak V. M., Suleimanov A. K., Trusov A. A., Van K. V., Zamozhniaya N. G. East European Craton: Early Precambrian history and 3D models of deep crustal structure. Geol. Soc. of Amer., Special Paper, 2015, vol. 510, 433 p.

21. Artemieva I. M. Global $1^{\circ} \times 1^{\circ}$ thermal model TC1 for the continental lithosphere: Implications for lithosphere secular evolution. Tectonophysics. 2006, vol. 416, pp. 245-277. DOI: https://doi.org/10.1016/j.tecto.2005.11.022

22. Muravina O. M. Metodologiya postroeniya kompleksnykh modelei litosfery platformennykh oblastei $v$ usloviyakh nepolnoty informatsii: avtoreferat dis.... d-ra tekhn. nauk [Methodology for constructing complex models of the lithosphere of platform areas in conditions of incomplete information: abstract of thesis. ... Dr. Tech. sciences.]. Moscow, In-t fiziki Zemli im. O.Yu. Shmidta RAN, Voronezh, 2016, 49 p.

23. Rybach L. Determination of the heat production rate. In: Haenel R., Rybach L., Stegena, L. (Eds.). Handbook of Terrestrial Heat-Flow Density Determination. Kluwer Academic Publishers. Dordrecht. 1988. P. 125-142. DOI: https://doi.org/.1007/978-94-009-2847-3

24. Ruedas T. Radioactive heat production of six geologically important nuclides. Geochemistry, Geophysics, Geosystems, 2017, vol. 18, no. 9, pp. 3530-3541. DOI: https://doi.org/10.1002/2017GC006997.

25. Chiozzi P., De Felice P., Faziob A., Pasquale V., Verdoya M. Laboratory application of $\mathrm{NaI}(\mathrm{Tl}) \gamma$-ray spectrometry to studies of natural radioactivity in geophysics. Applied Radiation and Isotopes, 2000, vol. 53, pp. 127-132.

26. Goes S., Hasterok D., Schutt D., Klöcking M. Continental lithospheric temperatures: A review. Physics of the Earth and Planetary Interiors, 2020, vol.306, 106509. DOI: https://doi.org/10.1016/j.pepi.2020.10650

27. Teilor S. R., Mak-Lennan S. M. Kontinental'naya kora: ee sostav i evolyutsiya [Continental crust: its composition and evolution.]. Moscow, Mir publ., 1988, 384 p. (In Russ.)

28. McDonough W. F., Sun S.-s. Chemical and isotopic systematics of oceanic basalts: implications for mantle composition and processes. Geological Society, London, Special Publications, 1989, vol. 42, pp. 313-345. https://doi.org/10.1144/GSL.SP.1989.042.01.19

29. McDonough W. F., Sun S.-s. The composition of the Earth. Chemical Geology, 1995, vol. 120, pp. 223-253. DOI: https://doi.org/10.1016/0009-2541(94)00140-4

30. Molotkov S. P., Kostyukov V. I., Lositskii V. I. Krivtsov I. I., Zolototrubova E. I., Ponomareva R. N. Geologicheskaya karta
Voronezhskogo kristallicheskogo massiva masshtaba $1: 500000$ [Geological map of the Voronezh crystalline massif on a scale of 1: 500,000.]. MPR RF, GPP «Voronezhgeologiya», OAO «Belgorodgeologiya», VGU, NKPR «Khors» publ., Voronezh, 1999. (In Russ.)

31. Terentiev R. A., Savko K. A., Skryabin V. Yu., Korish E. Kh. Petrotype of the Paleoproterozoic tonalite - trondhjemite - granodiorite Usman complex of the Losev structural-formation zone (Voronezh crystalline massif). Vestnik Voronezhskogo gosudarstvennogo universiteta. Seriya: Geologiya - Proceedings of Voronezh State University. Series: Geology, 2015, no. 4, pp. 42-60. (In Russ.)

32. Shchipanskii A. A., Samsonov A. V., Petrova A. Yu., Larionova Yu. O. Geodinamika vostochnoi okrainy Sarmatii v paleoproterozoe [Geodynamics of the eastern margin of Sarmatia in the Paleoproterozoic]. Geotektonika - Geotectonics, 2007, no. 1, pp. 43-70. (In Russ.)

33. Terentiev R. A. Manifestation of syn- and post-collisional granites of the Losev suture zone (Voronezh crystalline massif). Vestnik Voronezhskogo gosudarstvennogo universiteta. Seriya: Geologiya - Proceedings of Voronezh State University. Series: Geology, 2013, no. 2, pp. 70-85. (In Russ.)

34. Terentiev R. A., Savko K. A., Santosh M., Korish E. H., Sarkisyan L. S. Paleoproterozoic granitoids of the Losevo terrane, East European Craton: Age, magma source and tectonic implications. Precambrian Research, 2016, vol. 287, pp. 48-72. DOI: https://doi.org/10.1016/j.precamres.2016.10.015

35. Terentiev R.A., Savko K.A. Mineral thermobarometry and geochemistry of Paleoproterozoic magnesian-potassium granitoids of the Pavlovsk pluton, East European Craton. Vestnik Voronezhskogo gosudarstvennogo universiteta. Seriya: Geologiya Proceedings of Voronezh State University. Series: Geology, 2017, no. 3, pp. 34-45. (In Russ.)

36. Terentiev R. A., Savko K. A., Petrakova M. E., Santosh M., Korish E. H. Paleoproterozoic granitoids of the Don terrane, EastSarmatian Orogen: age, magma source and tectonic implications. Precambrian Research, 2020, vol. 346, no. 105790. DOI: https://doi.org/10.1016/j.precamres.2020.10579

37. Savko K. A., Samsonov A. V., Bazikov N. S., Larionova Yu. O., Khiller V. V., Votyakov S. L., Skryabin V. Yu., Kozlova E. N. Granitoids East of the Voronezh crystalline massif: geochemistry, Th-U-Pb age and petrogenesis. Vestnik Voronezhskogo gosudarstvennogo universiteta. Seriya: Geologiya - Proceedings of Voronezh State University. Series: Geology, 2011, no. 2, pp. 98-115. (In Russ.)

38. Savko K. A., Samsonov A. V., Larionov A. N., Larionova Yu. O., Bazikov N. S. Paleoproterozoic granites of A- and Stypes in the east of the Voronezh crystalline massif: geochronology, petrogenesis and tectonic setting of formation. Petrology, 2014, vol. 22 , no. 3, pp. 235-264. DOI: https://doi.org/10.7868/ S0869590314030054 (In Russ.)

39. Savko K. A., Terent'ev R. A. Geochronology of quartz diorites of the Romanov pluton of the Voronezh crystalline massif. Vestnik Voronezhskogo gosudarstvennogo universiteta. Seriya: Geologiya - Proceedings of Voronezh State University. Series: Geology, 2017, no. 2, pp. 74-80. (In Russ.)

40. Terentiev R. A., Savko K. A., Santosh M. Paleoproterozoic crustal evolution in the East Sarmatian Orogen: Petrology, geochemistry, Sr-Nd isotopes and zircon U-Pb geochronology of andesites from the Voronezh massif, Western Russia. Lithos, 2016, vol. 246-247, pp. 61-80. DOI: https://doi.org/10.1016/j.lithos.2015.12.025

41. Terentiev R. A., Savko K. A., Strik Yu. N. Paleoproterozoic andesites of the eastern part of the Voronezh crystalline massif (East Sarmatian Orogen): geochemistry and petrogenesis. Vestnik Voronezhskogo gosudarstvennogo universiteta. Seriya: Geolo- 
giya - Proceedings of Voronezh State University. Series: Geology, 2016, no. 1, pp. 66-75. (In Russ.)

42. Savko K. A., Samsonov A. V., Bazikov N. S. Metaterrigenous rocks of the Vorontsov series of the Voronezh crystalline massif: geochemistry, formation features and sources of drift. Vestnik Voronezhskogo gosudarstvennogo universiteta. Seriya: Geologiya - Proceedings of Voronezh State University. Series: Geology, 2011, no. 1, pp. 70-94. (In Russ.)

43. Terentiev R. A., Savko K. A., Bazikov N. S. Geochemistry and crystallization conditions of rocks of gabbrodiorite - anorthosite and monzogranite intrusions of the Losevo structural-formational zone (Voronezh crystalline massif). Vestnik Voronezhskogo gosudarstvennogo universiteta. Seriya: Geologiya - Proceedings of Voronezh State University. Series: Geology, 2014, no. 4, pp. 37-52. (In Russ.)

44. Terentiev R. A., Savko K. A., Santosh M. Post-collisional two-stage magmatism in the East Sarmatian Orogen, East European Craton: evidence from the Olkhovsky ring complex. Journal of the Geological Society, 2018, vol. 175(1):86. DOI: https://doi.org/10.1144/jgs2017-017

45. Terentiev R. A., Savko K. A., Bazikov N. S., Pilyugin S. M. Dikes of high-alumina norites and diorites in the Elan-Kolenovsky mafic-ultramafic pluton of the eastern Voronezh crystalline massif: mineralogy, geochemistry, crystallization conditions. Vestnik Voronezhskogo gosudarstvennogo universiteta. Seriya: Geologiya - Proceedings of Voronezh State University. Series: Geology, 2015, no. 3, pp. 35-49. (In Russ.)

46. Terentiev R. A., Savko K. A. High-Mg low-Ti gabbro-granite series in the Paleoproterozoic of Eastern Sarmatia: geochemistry and formation conditions. Geologiya i geofizika - Geology and Geophysics, 2016, vol. 57, no. 6, pp. 1155-1183. DOI: https://doi.org/10.15372 / GiG20160605

47. Terentiev R. A. Geochemistry and stratigraphy of rocks from the metaterrigenous section of the Strelitskaya strata of the Losevskaya series of the Voronezh crystalline massif. Article II: Geochemistry. Vestnik Voronezhskogo gosudarstvennogo universiteta. Seriya: Geologiya - Proceedings of Voronezh State University. Series: Geology, 2013, no. 1, pp. 127-138. (In Russ.)

48. Terentiev R. A. Geochemistry and paleogeodynamic reconstructions of volcanogenic rocks of the Losevskaya series of the Voronezh crystalline massif: significance for lithological and stratigraphic dissection. Vestnik Voronezhskogo gosudarstvennogo universiteta. Seriya: Geologiya - Proceedings of Voronezh State University. Series: Geology, 2016, no. 4, pp. 31-43. (In Russ.)

49. Terentiev R. A., Savko K. A., Santosh M. Paleoproterozoic evolution of the arc-back-arc system in the east Sarmatian orogen (East European Craton): zircon shrimp geochronology and geochemistry of the Losevo volcanic suite. American Journal of Science, 2017, vol. 317, pp. 707-753. DOI: https://doi.org/10.2475/06.2017.03

50. Savko K. A., Samsonov A. V., Salnikova E. B., Larionov A. N., Chervyakovskaya M. V., Bazikov N. S., Korish E. Kh. Geochronology of TTG association in the mesoarchean of the Kursk block Eastern Sarmatia. Vestnik Voronezhskogo gosudarstvennogo universiteta. Seriya: Geologiya - Proceedings of Voronezh State University. Series: Geology, 2019, no. 2, pp. 70-80. (In Russ.)

51. Savko K. A., Samsonov A. V., Larionov A. N., Chervyakovskaya M. V., Korish E. H., Larionova Y. O., Bazikov N. S., Tsybulyaev S. V. A buried Paleoarchean core of the Eastern Sarmatia, Kursk block: U-Pb, Lu-Hf and Sm-Nd isotope mapping and paleotectonic application. Precambrian Research, 2021, vol. 353, no. 106021. https://doi.org/10.1016/j.precamres.2020.106021

52. Savko K. A., Samsonov A. V., Bazikov N. S., Kozlova E. N. Paleoproterozoic granitoids of the Tim-Yastrebov structure of the
Voronezh crystalline massif: geochemistry, geochronology and sources of melts. Vestnik Voronezhskogo gosudarstvennogo universiteta. Seriya: Geologiya - Proceedings of Voronezh State University. Series: Geology, 2014, no. 2, pp. 56-78. (In Russ.) 53. Korish E. Kh., Savko K. A., Samsonov A. V., Chervyakovskaya M. V. Paleoproterozoic diorites of the Trosnyansk massif of the Kursk block of Sarmatia: U-Pb age, isotope systematics and sources of melts. Vestnik Voronezhskogo gosudarstvennogo universiteta. Seriya: Geologiya - Proceedings of Voronezh State University. Series: Geology, 2020, no. 1, pp. 87-99. (In Russ.) DOI: https://doi.org/10.17308 / geology.2020.1 / 2517

54. Savko K.A., Korish E. Kh., Pilyugin S.M., Polyakova T.N. Phase equilibria of rare-earth minerals during metamorphism of carbonaceous shales of the Tim-Yastrebovskaya structure, Voronezh crystalline massif. Petrologiya - Petrology. 2010, vol. 18, no. 4, pp. 402-433. (In Russ.)

55. Korish E. Kh., Savko K. A. Geochemistry of high-carbon shales of the Tim-Yastrebov structure (Voronezh crystalline massif). Vestnik Voronezhskogo gosudarstvennogo universiteta. Seriya: Geologiya - Proceedings of Voronezh State University. Series: Geology, 2010, no. 2, pp. 108-116. (In Russ.)

56. Savko K. A., Tsybulyaev S. V., Korish E. Kh. Metabasites of the Tim-Yastrebovskaya and Avila riftogenic structures on the eastern margin of Sarmatia: geochemistry, sources of melts and geological correlations. Vestnik Voronezhskogo gosudarstvennogo universiteta. Seriya: Geologiya - Proceedings of Voronezh State University. Series: Geology, 2016, no. 2, pp. 51-65. (In Russ.)

57. Tsybulyaev SV, Savko K. A., Samsonov A. V., Korish E. Kh. Paleoproterozoic riftogenic volcanic rocks of the OIB and MORB types of the Kursk block of eastern Sarmatia: petrology and geodynamics. Petrologiya - Petrology, 2021, vol. 29, no. 2, pp. 136171. (In Russ.) DOI: https://doi.org/10.31857 /S0869590321020060

58. Savko K. A., Samsonov A. V., Kholina N. V., Larionov A. N., Zaitseva M. V., Korish E. H., Bazikov N. S., Terentiev R. A. 2.6 Ga high-Si rhyolites and granites in the Kursk Domain, Eastern Sarmatia: Petrology and application for the Archaean palaeocontinental correlations. Precambrian Research, 2019, vol. 322, pp. 170-192. DOI: https://doi.org/10.1016/j.precamres.2019.01.006

59. Savko K. A., Korish E. Kh., Bazikov N. S., Samsonov A. V., Sal'nikova E. B., Kotov A. B., Kovach V. P., Larionov A. N. The mesoarchean tonalite-trondhjemite-granodiorite associations of Eastern Sarmatia: age and geological setting. Stratigraphy and Geological Correlation, 2019, vol. 27, no. 5, pp. 499-513.

60. Tsybulyaev S. V., Savko K. A. Geochemical typification of Paleoproterozoic volcanics of the bimodal series of the Kurbakinskaya suite of the Kursk block of Eastern Sarmatia. Vestnik Voronezhskogo gosudarstvennogo universiteta. Seriya: Geologiya - Proceedings of Voronezh State University. Series: Geology, 2017, no. 1, pp. 61-75. (In Russ.)

61. Savko K. A., Tsybulyaev S. V. Paleoproterozoiskie postkollizionnye vulkanity bimodal'noi serii kurbakinskoi svity Voronezhskogo kristallicheskogo massiva [Paleoproterozoic postcollisional volcanics of the bimodal series of the Kurbakinskaya suite of the Voronezh crystalline massif]. Granity $i$ evolyutsiya Zemli: mantiya $i$ kora $v$ granitoobrazovanii. Materialy III mezhdunarodn. geol. konf.[Granites and the evolution of the Earth: mantle and crust in granite formation. Materials III international. geol. Conf.,], 2017, Ekaterinburg: IGG UrO RAN, 2017, pp. 259-261. (In Russ.)

62. Savko K. A., Bazikov N. S., Artemenko G. V.Geochemical evolution of the banded iron formations of the Voronezh crystalline massif in the early precambrian: sources of matter and geochronological constraints. Stratigraphy and Geological Correlation, 2015, vol. 23, no. 5, pp. 451-467. 
63. Savko K. A., Ovchinnikova M. Y., Kuznetsov A. B. Carbonate deposits of Eastern Sarmatia (early precambrian ignateevo formation, Kursk block): sedimentation conditions and paleocontinental correlations. Stratigraphy and Geological Correlation, 2020, vol. 28, no. 4, pp. 343-364 DOI: https://doi.org/10.1134/S0869593820030107

64. Savko K. A., Kholina N. V., Samsonov A. V., Korish E. Kh., Chervyakovskaya M. V., Bazikov N. S., Larionov A. N. Petrotype of the Neoarchean Ataman complex of granites of the Kursk block Sarmatia: geochemistry, geochronology, isotope systematics. Vestnik Voronezhskogo gosudarstvennogo universiteta. Seriya: Geologiya - Proceedings of Voronezh State University. Series: Geology, 2020, no. 2, pp. 20-43. (In Russ.) DOI: https://doi.org/10.17308 / geology.2020.2 / 2857

65. Tsybulyaev S. V., Savko K. A., Chervyakovskaya M. V. Paleoproterozoic andesite porphyrites of the Kursk block of Eastern Sarmatia: geochemistry and the source of melts. Vestnik Voronezhskogo gosudarstvennogo universiteta. Seriya: GeologiyaProceedings of Voronezh State University. Series: Geology, 2019, no. 1, pp. 26-38. (In Russ.) DOI: https://doi.org/10.17308/geology.2019.1/1701

66. Tsybulyaev S. V., Savko K. A. U-Pb isotope age and tectonic position of Paleoproterozoic andesite porphyrites of the Kursk block of eastern Sarmatia. Vestnik Voronezhskogo gosudarstvennogo universiteta. Seriya: Geologiya - Proceedings of Voronezh State University. Series: Geology, 2018, no. 3, pp. 29-35. (In Russ.) DOI: https://doi.org/10.17308/geology.2018.3/1559

67. Bibikova E. V., Bogdanova S. V., Postnikov A. V., Popova L. P., Kirnozova T. I., Fugzan M. M., Glushchenko V. V. Junction zone of Sarmatia and Volga-Uralia : isotope-geochronological characteristics of supracrustal rocks and granitoids. Stratigraphy and Geological Correlation, 2009, vol. 17, no. 6, pp. 3-16. (In Russ.)

68. Bogdanova S., De Waele B., Bibikova E., Belousova E.A., Postnikov A.V., Fedotova A.A., Popova L.P. Volgo-Uralia: the first $\mathrm{U}-\mathrm{Pb}, \mathrm{Lu}-\mathrm{Hf}$ and $\mathrm{Sm}-\mathrm{Nd}$ isotopic evidence of preserved Paleoarchean crust. American Journal of Science, 2010, vol. 310, pp. 1345-1383. DOI: https://doi.org/10.2475/10.2010.06 69. Bibikova E. V., Bogdanova S. V., Postnikov A. V., Fedotova A. A., Claesson S., Kirnozova T., Fugzan M. M., Popova L. P. Ural segment of the East European Craton: isotopic-geochronological study of terrigenous zircon from metasedimentary rocks of the Bolshoi-Cheremshan Group and their Sm-Nd model age. Stratigraphy and Geological Correlation, 2015, vol. 23, no. 1, pp. 3. (In Russ.) DOI: https://doi.org/10.7868 / S0869592X15010032 70. Bogdanova S. V., Belousova E., Waele B. D., Larionov A. N., Piazolo S., Postnikov A. V., Samsonov A. V. Palaeoproterozoic reworking of early Archaean lithospheric blocks: Rocks and zircon records from charnockitoids in Volgo-Uralia. Precambrian Research, vol.360, 2021, no. 106224. DOI: doi.org/10.1016/j.precamres.2021.106224

71. Nosova A. A., Voznyak A. A., Lebedeva N. M., Bogdanova S. V., Page L., Savko K. A., Travin A. V., Yudin D. S., Larionov A. N., Postnikov A. V. Early cambrian syenite and monzonite magmatism in the southeast of the East European platform: petrogenesis and tectonic setting. Petrology, 2019, vol. 27, no. 4, pp. 329-369. DOI: https://doi.org/10.1134/S0869591119040064

72. Bibikova E. V., Lobach-Zhuchenko S. B., Artemenko G. V., Claesson S., Kovalenko A. V., Krylov I. N. Late Archean magmatic complexes of the Azov terrane of the Ukrainian shield: geological position, isotopic age, sources of matter. Petrology, 2008, vol. 16, no. 3, pp. 227-247. (In Russ.)

73. Artemenko G. V., Lobach-Zhuchenko S. B., Bibikova E. V. Geologiya, vozrast i sostav arkheiskikh gornblenditov zapadnogo Priazov'ya [Geology, age and composition of Archean hornblendites of the western Azov Sea]. Geologicheskii zhurnal - Geological journal, 2008, no. 2, pp. 35-43. (In Russ.)

74. Mitrokhin A. V., Bogdanova S. V., Shumlyanskii L. V. Polibaricheskaya kristallizatsiya anortozitov Korostenskogo plutona (Ukrainskii shchit) [Polybaric crystallization of anorthosites of the Korosten pluton (Ukrainian shield)]. Mineralogichnii zhurnal-Mineralogical journal, 2008, vol. 30, no. 2, (156), pp. 3656. (In Russ.)

75. Shumlyanskii L. V., Bogdanova S. V. U-PB vozrast tsirkonov i geokhimicheskie osobennosti riolitov Ovruchskoi vpadiny, severo-zapadnyi raion Ukrainskogo shchita [U-PB age of zircons and geochemical features of rhyolites of the Ovruch depression, northwestern region of the Ukrainian]. Mineralogichnii zhurnal Mineralogical journal, 2009, vol. 31, no. 1 (159), pp. 40-49. (In Russ.)

76. Mitrokhin A. V., Bogdanova S. V., Bilan E. V. Petrologiya Malinskogo massiva rapakivi (Korostenskii pluton) [Petrology of the Malinsky massif rapakivi (Korosten pluton)]. Mineralogichnii zhurnal - Mineralogical journal, 2009, vol. 31, no. 2 (160), pp. 66-82. (In Russ.)

77. Bibikova E. V., Claessen S., Fedotova A. A., Artemenko G. V., Il'inskii L. C. Terrigennyi tsirkon arkheiskikh zelenokamennykh poyasov - istochnik informatsii o rannei kore Zemli: Priazov'e i Pridneprov'e, Ukrainskii shchit [errigenous zircon of the Archean greenstone belts - a source of information about the early crust of the Earth: Azov and Dnieper regions, Ukrainian shield]. Geokhimiya - Geochemistry, 2010, no. 9, pp. 899-916. (In Russ.) 78. Bibikova E. V., Fedotova A. A., Claessen S., Artemenko G. V., Anosova M. O. Early crust of the Azov domain of the Ukrainian shield: isotope-geochronological and geochemical study of terrigenous zircons from metasedimentary rocks of the Fedorov structure. Stratigraphy and Geological Correlation, 2012, vol. 20, no. 2, pp. 13-26. (In Russ.)

79. Bibikova E. V., Claesson S., Fedotova A. A., Stepanyuk L. M., Shumlyansky L. V., Kirnozova T. I., Fugzan M. M., Ilyinsky L. S. Izotopno-geokhronologicheskoe (U-Th-Pb, Lu-Hf) izuchenie tsirkonov arkheiskikh magmaticheskikh i metaosadochnykh porod Podol'skogo domena Ukrainskogo shchita [Isotope-geochronological (U-Th-Pb, Lu-Hf) study of zircons of Archean igneous and metasedimentary rocks of the Podolsk domain of the Ukrainian Shield]. Geokhimiya - Geochemistry, 2013, no. 2, pp. 99-121. (In Russ.) DOI: https://doi.org/10.7868 / S0016752513020039

80. Bogdanova S. V., Gintov O. B., Kurlovich D. M., Lubnina N. V., Mimmi K. M. Nilsson, Orlyuk M. I., Pashkevich I. K., Shumlyanskyy L. V., Starostenko V. I. Late Palaeoproterozoic mafic dyking in the Ukrainian Shield of Volgo-Sarmatia caused by rotation during the assembly of supercontinent Columbia (Nuna). Lithos, 2013, vol. 174, pp. 196-216. DOI: https://doi.org/10.1016/j.lithos.2012.11.002

81. Shumlyanskii L. V., Mitrokhin A. V., Dyushen Zh-K., Bogdanova S. V., Billstrem Sh., Omel'chenko A. N., Baginski B. Petrology of subalkaline dolerite dikes of the Korosten complex, northwestern region Ukrainian shield [Petrologiya daek subshchelochnykh doleritov Korostenskogo kompleksa, severo-zapadnyi raion Ukrainskogo shchita]. Mineralogichnii zhurnal Mineralogical journal, 2018, vol. 40, no. 1 (195), pp. 32-52. (In Russ.) DOI: https://doi.org/10.15407/mineraljournal.40.01.032 82. Shumlyanskyy L., Wilde S. A., Nemchin A. A., Claesson S., Billstrom K., Baginski B. Eoarcean rock association in the Dniester-Bouh domain of the Ukrainian shield: a suite of LILEdepleted enderbites and mafic granulites. Precambrian Research, 2021, vol. 352, 106101. DOI: j.precamres.2020.106101

83. Vejelytea I., Bogdanova S., Skridlaited G. Early Mesoproterozoic magmatism in northwestern Lithuania: A new $\mathrm{U}-\mathrm{Pb}$ zircon 
dating. Estonian Journal of Earth Sciences, 2015, vol. 64(3), pp. 189-198. DOI: https://doi.org/10.3176/earth.2015.26

84. Glaznev V. N., Muravina O. M., Zhavoronkin V. I., Lebedev I.P., Voronova T. A. Petroplotnostnaya karta dokembriiskogo fundamenta Voronezhskogo kristallicheskogo massiva. Masshtab 1:1000 000. Ob"yasnitel'naya zapiska [Petro-density map of the Precambrian basement of the Voronezh crystalline massif. Scale 1: 1,000,000. Explanatory note.]. Voronezh, «Nauchnaya kniga» publ., 2020, 101 p. (In Russ.)

85. Krasovskii S. S. Otrazhenie dinamiki zemnoi kory kontinental'nogo tipa $v$ gravitatsionnom pole [Reflection of the dynamics of the earth's crust of the continental type in the gravitational field]. Kiev, Naukova dumka publ., 1981, 264 p. (In Russ.) 86. Litosfera Tsentral'noi i Vostochnoi Evropy: Vostochno-Evropeiskaya platform [Lithosphere of Central and Eastern Europe: East European Platform.]. Red.: V.B. Sollogub. Kiev, Naukova dumka publ., 1989. 188 p. (In Russ.)

87. Galitchanina L. D., Glaznev V. N., Mitrofanov F. P., Olesen O., Henkel H. Surface density characteristics of the Baltic Shield and adjacent territories. Norges Geologiske Undersøkelse. Special Publication «Geology of the Eastern Finnmark - Western Kola Peninsula Region». Proceedings of the 1st. International Barents Symposium «Geology and Minerals in the Barents Region». Eds. D. Roberts, Ø.Nordgulen. 1995, pp. 349-354.

88. Fizicheskie svoistva osadochnykh porod Vostochno-Evropeiskoi platform [Physical properties of sedimentary rocks of the East European platform]. Red.: N. V. Podoba, M. L. Ozerskaya. Moscow, Nedra publ., 1975, 280 p. (In Russ.)

89. Sarkisova N. P. Gosudarstvennaya geologicheskaya karta Rossiiskoi Federatsii. M-37, 38 (Voronezh). Masshtab 1: 1000000 [State geological map of the Russian Federation. M-37, 38 (Voronezh). Scale 1: 1,000,000.]. Moscow, MPR RF. 2001. 90. Glaznev V. N., Muravina O. M., Voronova T. A., Kholin V. $\mathrm{M}$. Estimation of the thickness of the gravitational layer of the earth's crust of the Voronezh crystalline massif. Vestnik Voronezhskogo gosudarstvennogo universiteta. Seriya: GeologiyaProceedings of Voronezh State University. Series: Geology, 2014, no. 4, pp.78-84. (In Russ.)

91. Rudnick R. L., Gao S. Composition of the Continental Crust. In: Treatise on Geochemistry (Second Edition). Eds.: R.L. Rudnick. Elsevier, 2014, vol. 4, pp. 1-51. DOI: https://doi.org/10.1016/B978-0-08-095975-7.00301-6

92. Artemieva I. M., Thybo H., Jakobsen K., Sorensen N. K.,
Nielsen L.S.K. Heat production in granitic rocks: Global analysis based on a new data compilation GRANITE2017. Earth-Science Review, 2017, vol. 172, pp. 1-26. DOI: 10.1016/j.earscirev.2017.07.003

93. Vila M., Fernandez M., Jiménez-Munt I. Radiogenic heat production variability of some common lithological groups and its significance to lithospheric thermal modeling. Tectonophysics, 2010, vol. 490(3-4), pp. 152-164. DOI: https://doi.org/10.1016/j.tecto.2010.05.003

94. Hasterok D., Webb J. On the radiogenic heat production of igneous rocks. Geoscience Frontiers, 2017, vol. 8(5), pp. 919 940. DOI: https://doi.org/10.1016/j.gsf.2017.03.006

95. Muravina O. M. Metod gruppovogo ucheta argumentov pri analize geofizicheskikh dannykh [Method of group accounting of arguments in the analysis of geophysical data]. Geofizika - Geophysics, 2012, no. 6, pp. 16-20. (In Russ.)

96. Gard M., Hasterok D., Hand M., Cox G. Variations in continental heat production from $4 \mathrm{Ga}$ to the present: Evidence from geochemical data. Lithos, 2019, vol. 342-343, pp. 391-406. DOI: 10.1016/j.lithos.2019.05.034

97. Hasterok D., Gard M., Cox G., Hand M. A 4 Ga record of granitic heat production: implications for geodynamic evolution and composition of the early Earth. Precambrian Research, 2019, 331 , 105375.

DOI: https://doi.org/10.1016/j.precamres.2019.105375

98. Savko K.A., Kholin V.M., Bazikov N.S., Samsonov A.V The Sarmatia megablock as a fragment of the Vaalbara supercontinent: correlation of geological events at the archean-paleoproterozoic transition. Stratigraphy and Geological Correlation. 2017, vol. 25, no. 2, pp. 123-145. DOI: https://doi.org/10.1134/S0869593817020058

99. Balashov Yu. A., Glaznev V. N., Vliyanie plyumovogo magmatizma na dinamiku dokembriiskogo koroobrazovaniya [Influence of plume magmatism on the dynamics of Precambrian crust formation]. Doklady RAN - RAS reports, 2004, vol. 395, no. 1, pp. 78-81. (In Russ.)

100. Arzamastsev A. A., Glaznev V. N. Plyum-litosfernoe vzaimodeistvie $\mathrm{v}$ usloviyakh drevnego sublitosfernogo mantiinogo kilya na primere Kol'skoi shchelochnoi provintsii [Plumelithospheric interaction under conditions of an ancient sublithospheric mantle keel on the example of the Kola alkaline province]. Doklady RAN-RAS reports, 2008, vol. 419, no. 4, pp. 515518. (In Russ.)
Глазнев Виктор Николаевич - д.ф.-м.н., профессор, заведующий кафедрой геофизики, Воронежский государственный университет, Воронеж, Российская Федерация; е-mail:

glaznev@geol.vsu.ru;

ORCID https://orcid.org/0000-0002-1016-1866

Муравина Ольга Михайловна - д. т. н., профессор кафедры геофизики, Воронежский государственный университет, Воронеж, Российская Федерация; e-mail: muravina@geol.vsu.ru; ORCID https://orcid.org/0000-0003-4772-0825

Мини Михаил Вениаминович - д. г.-м. н., главный научный сотрудник, Геологический институт РАН (ГИН РАН), Москва, Российская Федерация; e-mail: michael-mints@yandex.ru; ORCID http://orcid.org/0000-0001-7015-6586

Чернышова Дарья Максимовна - магистр кафедры геофизики Воронежский государственный университет, Воронеж, Российская Федерация; e-mail: dasha.che90@gmail.com

Авторы прочитали и одобрили окончательный вариант рукописи.
Victor N. Glaznev - Dr. habil. in Physics and Mathematics, Professor, Head of the Department of Geophysics, Voronezh State University, Voronezh, Russian Federation; e-mail: glaznev@geol.vsu.ru; ORCID https://orcid.org/0000-0002-1016-1866

Olga M. Muravina - Dr. habil. in Technical Sciences, Professor, Department of Geophysics, Voronezh State University, Voronezh, Russian Federation; e-mail: muravina@geol.vsu.ru; ORCID https://orcid.org/0000-0003-4772-0825

Mikhail V. Mints - Dr. habil. in Geol.-Min., Chief Researcher, Geological institute of RAS, Moscow, Russian Federation, e-mail: michael-mints@yandex.ru; ORCID http://orcid.org/0000-0001-70156586

Daria M. Chernyshova - Master of Geophysical Department, Voronezh State University, Voronezh, Russian Federation; e-mail: dasha.che90@gmail.com

All authors have read and approved the final manuscript. 